\title{
Conflicts of Interest in Japanese Insolvencies: The Problem of Bank Rescues
}

\section{Citation}

Yoshiro Miwa \& J. Mark Ramseyer, Conflicts of Interest in Japanese Insolvencies: The Problem of Bank Rescues, 6 Theoretical Inq. L. 301 (2005).

\section{Published Version}

http://www.bepress.com/til/default/vol6/iss2/art2

\section{Permanent link}

http://nrs.harvard.edu/urn-3:HUL.InstRepos:2766351

\section{Terms of Use}

This article was downloaded from Harvard University's DASH repository, and is made available under the terms and conditions applicable to Other Posted Material, as set forth at http:// nrs.harvard.edu/urn-3:HUL.InstRepos:dash.current.terms-of-use\#LAA

\section{Share Your Story}

The Harvard community has made this article openly available.

Please share how this access benefits you. Submit a story.

\section{Accessibility}




\section{Theoretical Inquiries in Law}

Volume 6, Number 2

July 2005

Article 2

The Role AND Limits of LEGAl REgulation of CONFLiCTS

OF INTEREST (PART II)

\section{Conflicts of Interest in Japanese Insolvencies: The Problem of Bank Rescues}

Yoshiro Miwa*

\author{
J. Mark Ramseyer ${ }^{\dagger}$
}

$\dagger$

Copyright (C) 2005 by Theoretical Inquiries in Law, The Cegla Center for Interdisciplinary Research of the Law, The Buchmann Faculty of Law, Tel Aviv University.

All rights reserved. No part of this publication may be reproduced, stored in a retrieval system, or transmitted, in any form or by any means, electronic, mechanical, photocopying, recording or otherwise, without the prior written permission of the publisher. Theoretical Inquiries in Law is published electronically and in paper by The Cegla Center for Interdisciplinary Research of the Law, The Buchmann Faculty of Law, Tel Aviv University.

Theoretical Inquiries in Law is one of The Journals of Legal Scholarship, produced by The Berkeley Electronic Press. 


\title{
Conflicts of Interest in Japanese Insolvencies: The Problem of Bank Rescues
}

\author{
Yoshiro Miwa \& J. Mark Ramseyer*
}

\begin{abstract}
Economists and legal scholars routinely posit an implicit contract between Japanese firms and their principal lender (called their "main bank"). Under this arrangement, the bank implicitly agrees to rescue the firm (through financial and managerial help) when times turn bad. Out of court, it rescues the firm from insolvency. Not only does it save the investments specific to the troubled firm, it lowers the use of costly bankruptcy proceedings and cuts the costs of those bankruptcy procedures firms do occasionally invoke.

Given the creditor-shareholder conflicts of interest that arise as firms approach insolvency, such arrangements would seem unstable. Yet according to a long sociological tradition, conflicts of interest matter less in Japan than in the West. According to the emerging economic and legal tradition, Japanese economic actors do face those conflicts, but keep them in check through reputational concerns, close-knit ties, and government supervision.
\end{abstract}

* Professor of Economics at the University of Tokyo and Mitsubishi Professor of Japanese Legal Studies at Harvard University, respectively. We gratefully acknowledge the helpful comments and suggestions of Yoshitaka Fukui, David Gilo, Curtis Milhaupt, Robert Rasmussen, George Triantis, Elizabeth Warren, and workshop participants at the University of Pennsylvania and the University of Tokyo. We received generous financial assistance from the John M. Olin Program in Law, Economics and Business at the Harvard Law School (Ramseyer), the East Asian Legal Studies Program at the Harvard Law School (Miwa), the Center for International Research in the Japanese Economy at the University of Tokyo (Miwa), and the Business Law Center at the University of Tokyo (Ramseyer). 
Using two datasets of troubled firms from the 1970s and 1980s, we ask whether Japanese main banks in fact rescue distressed borrowers. We find no evidence that they do: large Japanese firms fail; when large firms approach insolvency, main banks do not increase the share of the firm's debt they bear; stronger ties between distressed firms and their main bank do not facilitate loans; and troubled firms do not try to preserve their main bank relationship.

All told, the claim that Japanese banks ever implicitly agreed to rescue firms is sheer myth. That Japanese banks let troubled firms fail is no recent development; it has been thus for decades. Conflicts of interest do indeed matter in Japan and long have. They matter enough to prevent precisely the incentive-incompatible rescue deals that scholars in the field so routinely posit.

\section{INTRODUCTION}

By a long sociological tradition, conflicts of interest in Japan largely do not matter. Japanese live lives so circumscribed by norms of loyalty and duty that firms need not concern themselves with the conflicts that plague their peers in the West. By the emerging economic and law-\&-economics approach, conflicts do matter in the Japanese business world. Yet they primarily matter in ways that firms overcome. Through close relationships, reputational concerns, and government supervision, Japanese firms resolve the conflicts of interest that stymie so many potential transactions in the West.

To understand the impact of conflicts of interest in Japan, we examine creditor-shareholder ties as firms approach insolvency. According to an increasingly large and theoretically sophisticated literature, the principal lender (called the "main bank") to a Japanese firm implicitly agrees to rescue it (through financial and managerial help) should it fall into distress. The claim should puzzle. After all, basic logic suggests that conflicts of interest between creditors and shareholders become most intense as firms approach insolvency. What logic suggests, however, the literature denies. Despite clear conflicts of interest, despite the absence of legally enforceable arrangements, despite the obvious incentive incompatibility - despite all this, according to the literature, firms and banks routinely keep their (implicit) word.

The implications for bankruptcy law follow straightforwardly. Because 
(at least so bankruptcy law proponents claim) ${ }^{1}$ firms typically embody substantial firm-specific tangible and intangible assets, society benefits if those that encounter financial distress can weather it intact. Unfortunately, conflicts of interest and informational asymmetries among creditors, managers, and shareholders often prevent them from doing so on their own. Hence bankruptcy: through the courts, creditors, debtors, and shareholders negotiate the terms of the deal that will salvage the firm-specific investments they have made.

In Japan, argue the specialists, the main bank accomplishes what bankruptcy judges do in the U.S. at far less cost. Because all creditors recognize that the main bank bears responsibility for rescuing the firm, collective action problems disappear. Because the main bank monitors the firm assiduously, informational asymmetries between creditors and managers disappear as well. Engineer analogous arrangements elsewhere, the specialists imply, and social welfare will increase and the need for bankruptcy law fall.

The main bank literature encompasses a broad panoply of claims beyond this bank-rescue argument. Given that we discuss those claims elsewhere, ${ }^{2}$ we do not attempt a comprehensive critique here. Instead, we limit ourselves to the claims about bank rescues. We begin by summarizing the literature (Section I). To clarify the issues involved, we introduce several examples from the 1970s (Section II). We then explain our data and report our empirical results (Section III). We find no evidence that Japanese banks rescued troubled firms either in the depressed 1970s or in the booming 1980s. We conclude by speculating about what role banks do play (Section IV).

1 The claim is rarely tested and dubious at best, as Douglas G. Baird \& Robert K. Rasmussen, The End of Bankruptcy, 55 Stan. L. Rev. 751 (2002) shows.

2 Yoshiro Miwa \& J. Mark Ramseyer, The Myth of the Main Bank: Japan and Comparative Corporate Governance, 27 Law \& Soc. Inquiry 401 (2002) [hereinafter Miwa \& Ramseyer, The Myth of the Main Bank]; Yoshiro Miwa \& J. Mark Ramseyer, Financial Malaise and the Myth of the Misgoverned Bank, in Global Markets, Domestic Institutions: Corporate Law and Governance in a New Era of Cross-Border Deals 339 (Curtis J. Milhaupt ed., 2003) [hereinafter Miwa \& Ramseyer, Financial Malaise]; Yoshiro Miwa \& J. Mark Ramseyer, Who Appoints Them, What Do they Do? Evidence on Outside Directors from Japan, 14 Econ. \& Mgmt. Strategy (forthcoming 2005) [hereinafter Miwa \& Ramseyer, Outside Directors]; Yoshiro Miwa \& J. Mark Ramseyer, Does Relationship Banking Matter? The Myth of the Japanese Main Bank, 2 J. Empirical Legal Stud. (forthcoming 2005) [hereinafter Miwa \& Ramseyer, Relationship Banking]. 


\section{CONFLICTS OF INTEREST IN JAPAN}

\section{A. The Tradition}

Few traditions in Japanese business studies trace a nobler lineage than the notion that Japanese executives keep their word. According to some, they keep it out of an ingrained sense of Confucian loyalty. According to others, they keep it out of an austere samurai tradition. And according to still others, they keep it because they live in such a closely-knit circle that social norms bind tightly.

The classic in the genre is Kawashima. ${ }^{3}$ A pioneer of law \& society research in Japan, Takeyoshi Kawashima argued that Japanese live within a closelyknit hierarchical world that forestalls a strong sense of individual entitlement ("legal consciousness," he called it). Absent that sense, they cannot, do not, and need not negotiate the elaborate contractual safeguards that Westerners take for granted.

In the decades since, scholars have repeated this argument endlessly. Among prominent recent writers, Ronald Dore ${ }^{4}$ has perhaps pushed it farthest. Because of their social organization, claims Dore, Japanese executives indulge less selfishness and practice more benevolence than their American and British counterparts. With less self-interested executives, Japanese firms need not concern themselves with conflicts of interest as obsessively as their American and British competitors. ${ }^{5}$

Other writers have been more skeptical — but, alas, not skeptical enough. They routinely assert, for example, that Japanese firms exploit women but never explain why other firms do not use the chance to hire good employees cheap by treating women fairly. They claim Japanese firms cheat consumers - but do not explain why rival firms do not steal market share by exposing the fraud. They claim big Japanese firms exploit their smaller

3 Takeyoshi Kawashima, Dispute Resolution in Contemporary Japan, in Law in Japan: The Legal Order in a Changing Society 41 (Arthur Taylor von Mehren ed., 1963); Takeyoshi Kawashima, The Legal Consciousness of Contract in Japan, 7 Law in Japan 1 (Charles Stevens trans., 1974).

4 Ronald Dore, Stock Market Capitalism: Welfare Capitalism; Japan and Germany versus the Anglo-Saxons (2000).

5 A parallel tradition in the sociological, legal, and business scholarship on Japan asserts (incomprehensibly to anyone with a serious background in economics) that shareholders simply do not matter in Japan. This obviously makes it easier for scholars to ignore conflicts of interest in insolvency. 
subcontractors - but never explain why anyone becomes a subcontractor in the first place. They claim Japanese bureaucrats guide the economy but do not (beyond platitudes about Confucianism and demonstrably false claims about government power ${ }^{6}$ ) explain why firms do as bureaucrats say.

Even in finance, scholars routinely slight the impact of conflicts of interest. Some argue that Japanese banks extract substantial rents from the firms that use them as their main bank - but never explain why those firms do not switch banks. Some assert that firms in the keiretsu corporate groups pay higher interest rates to the group bank — but, again, without explaining why they do not take their business elsewhere. Indeed, even those other scholars who attribute all manner of virtue to the keiretsu never answer (or even pose) the obvious Chicago workshop question: If the keiretsu confer such benefits, why does market competition not lead all Japanese firms to join one and cause firms elsewhere to organize analogous arrangements?

\section{B. Conflicts during Economic Distress}

\section{Introduction}

As the examples from finance show, over the past two decades the practice of ignoring Japanese conflicts of interest has migrated into economics and law $\&$ economics. Most prominently, the practice appears in accounts of how Japanese firms negotiate insolvency. One might have thought insolvency the place where conflicts among shareholders, managers, and creditors become most pointed. By most accounts, though, in Japan those conflicts rarely surface.

The story begins with the "main bank." Although Japanese firms typically borrow from several banks, most observers claim they maintain an "implicit" contract with one of the several as their main bank. Under no legal obligation to do so, that bank then provides a variety of services. For purposes of this study, we focus on one: the main bank rescues borrowers in distress.

\section{Bank Rescues}

According to the conventional wisdom, the main bank implicitly agrees to save troubled borrowers. Just what the rescue entails varies from scholar to scholar, but most seem to believe that the main bank will lend money, resources, and personnel. As Hoshi \& Kashyap put it, when "firms [run] into

6 See Yoshiro Miwa \& J. Mark Ramseyer, Directed Credit? The Loan Market in High-Growth Japan, 13 J. Econ. \& Mgmt. Strategy 171 (2004). 
financial difficulty," the main bank "step[s] up and organize[s] a workout."7 By Aoki's account, it launches "rescue operations [that] prevent the premature liquidation of temporarily depressed, but potentially productive, firms."8 Milgrom \& Roberts claim it serves "as an ultimate risk-bearer in circumstances of financial distress,"9 and Macey \& Miller describe the resulting tradeoff as one where "firms sacrifice control and flexibility for the safety and security of a main bank relationship." ${ }^{10}$ Just as the centralized state in Eastern Europe would forestall wasteful failures by setting production schedules in advance, so the Japanese main bank prevents them by sending funds and experts as necessary.

And just as the mid-century Marxists had to finesse profound conflicts of interest to make their tales of the socialist Valhalla even plausibly coherent, so too current main bank theorists. Faced with borrowers in distress, they proclaim, Japanese main banks advance extra funds unsecured. ${ }^{11}$ They send their own staff (often as board directors) to revamp management. ${ }^{12}$ They guarantee the firm's debts..$^{13}$ They abandon their security interests and subordinate their claims to those of their competitors. ${ }^{14}$ And all this they do under no legal obligation, indeed with no written or unwritten agreement at all.

\section{Hoshi, Kashyap \& Scharfstein}

Of the many studies in the field, the best-known probably remain those by Hoshi, Kashyap \& Scharfstein. ${ }^{15}$ According to Hoshi et al., the closer the ties a firm maintains to its main bank, the less constraining it finds

7 Takeo Hoshi \& Anil Kashyap, Corporate Financing and Governance in Japan: The Road to the Future 5 (2001).

8 Masahiko Aoki, Information, Corporate Governance, and Institutional Diversity: Competitiveness in Japan, the USA, and the Transitional Economies 86 (Stacey Jehlik trans., 2000) (1995).

9 Paul Milgrom \& John Roberts, Complementarities and Systems: Understanding Japanese Economic Organization, 9 Estudios Economicos 3, 24 (1994).

10 Jonathan R. Macey \& Geoffrey P. Miller, Corporate Governance and Commercial Banking: A Comparative Examination of Germany, Japan, and the United States, 48 Stan. L. Rev. 73, 85 (1995).

11 Takatoshi Ito, The Japanese Economy 116 (1992).

12 Randall Morck et al., Banks, Ownership Structure, and Firm Value in Japan, 73 J. Bus. 539, 540 (2000); Paul Sheard, Banks, Blockholders and Corporate Governance: The Role of External Appointees to the Board, in Japanese Firms, Finance and Markets 181 (Paul Sheard ed., 1996).

13 Aoki, supra note 8 , at 71 .

14 Id. at 83.

15 Takeo Hoshi et al., The Role of Banks in Reducing the Costs of Financial Distress in Japan, 27 J. Fin Econ. 67 (1990) [hereinafter Hoshi et al., The Role of Banks]; 
financial distress. As Bhandari \& Weiss explain the work, "the typically close relationship between a financing bank and a debtor firm in Japan reduces the dispersion and coordination problems among a firm's creditors" and creates a world with a "relative lack of conflict among creditors." ${ }^{16}$ In the end, not only does this cut the cost of financial distress to most firms, it reduces the "need for bankruptcy" in Japan and lowers the "costs of those bankruptcy reorganizations that do occur."

Given the price it pays to rescue troubled firms, a bank that implicitly agrees to supply such aid potentially faces a subgame-imperfect strategy. Given the resulting risk that it will renege, rational firms and banks should at least negotiate legally enforceable claims. They negotiate none. According to main bank theorists, they leave the deal "implicit." They do not just leave it unwritten: they leave it unspoken to boot.

Faced with why Japanese firms would rely on unspoken assumptions in this conflict-ridden environment, Sheard dismisses the question as "somewhat of a puzzle." ${ }^{17}$ Aoki claims Ministry of Finance bureaucrats manipulate branch bank license denials to engineer a world where banks implement the knife-edge optimal strategy: rescue firms if, but only if, financially distressed but economically healthy. ${ }^{18}$ By contrast, Rajan ${ }^{19}$ simply assures us that in Japan, "reputational concerns" make it all work.

In their more extended discussion of main bank financial assistance based on a 125-firm sample of distressed firms, Hoshi, Kashyap \& Scharfstein largely ignore the question. Given the costs of rescuing distressed firms, one might wonder how effectively banks could resolve the conflicts among

Takeo Hoshi et al., Bank Monitoring and Investment: Evidence from the Changing Structure of Japanese Corporate Banking Relationships, in Asymmetric Information, Corporate Finance, and Investment 105 (R. Glenn Hubbard ed., 1990); Takeo Hoshi et al., Corporate Structure, Liquidity, and Investment: Evidence from Japanese Industrial Groups, 106 Q.J. Econ. 33 (1991).

16 Jagdeep S. Bhandari \& Lawrence A. Weiss, Experiences of Other Countries, in Corporate Bankruptcy: Economic and Legal Perspectives 449, 449 (Jagdeep S. Bhandari \& Lawrence A. Weiss eds., 1996).

17 Paul Sheard, Reciprocal Delegated Monitoring in the Japanese Main Bank System, 8 J. Japanese \& Int'l Econ. 1, 17 (1994).

18 Aoki, supra note 8. One might have thought the distinction hard enough even for the executives at a firm's main bank to make. Yet according to Aoki, Ministry of Finance bureaucrats determine ex ante what level of branch banking application denials based on failures to rescue defaulting debtors will cause banks to adopt that optimal knife-edge rescue strategy: rescue if, but only if, a firm is economically healthy but financially distressed. For some of the many problems with this claim, see Miwa \& Ramseyer, The Myth of the Main Bank, supra note 2, at 408-09.

19 Raghuram G. Rajan, Review, 34 J. Econ. Lit. 1363, 1364 (1996). 
themselves. ${ }^{20}$ Answer Hoshi et al.: it "is clear to all members in the consortium that the main bank is responsible for helping the firm in times of distress."21 One might wonder whether the bank and firm would not face informational asymmetries that stymie close cooperation. Answer Hoshi et al.: "the main bank is probably well-informed about the firm and its prospects." 22

All this might be more plausible if firms and banks deliberately were to try to cut any of these deals. Yet not only do banks and firms never negotiate legally enforceable rescue contracts, they never even designate a bank as main bank. Hoshi, Kashyap \& Scharfstein's reference to the contrary notwithstanding, they do not even lend as consortia. ${ }^{23}$

Despite the superficial facility with which Hoshi, Kashyap \& Scharfstein describe the main bank arrangements, they themselves find it more ambiguous in practice. To partition their sample by the strength of the bank-firm relationship, ${ }^{24}$ they invoke the keiretsu. To identify the latter, however, they simply use the English version of one of several loan-based lists marketed in Japanese by a Marxist think-tank. ${ }^{25}$ Even this they find more ambiguous in practice than one might think and note that identifying the keiretsu ties "requires some judgment." 26

\section{The Project}

Ultimately, the question is not just why Japanese firms and banks do not draft rescue contracts explicitly. The question is whether they make such

20 Hoshi et al., The Role of Banks, supra note 15.

21 Id. at 73. They also write that "free-rider problems may be les severe [because of] the repeated participation of banks in lending consortiums." Id. at 73. As noted in the text, the banks do not lend as consortia. In addition, Hoshi et al., claim that "free-rider problems are less severe" because "there are fewer creditors and the main bank holds a large financial stake in the firm." Id. at 72-73. In fact, even during the 1960s, large Japanese firms borrowed only $15-20 \%$ of their debt from their main banks. See Miwa \& Ramseyer, The Myth of the Main Bank, supra note 2, at 419.

22 Hoshi et al., The Role of Banks, supra note 15, at 69.

23 Id. at 73.

24 Id. at 77-78.

25 In other words, they use the variation on the Keiretsu no kenkyu list, which appears in a 1984 article published in English by Nakatani (Iwao Nakatani, The Economic Role of Financial Corporate Grouping, in The Economic Analysis of the Japanese Firm 227 (Masahiko Aoki ed., 1984)) — to which they somewhat euphemistically refer as "Nakatani's (1984) refinement" of the list; thus, it is not the Dodwell equity-based list often used by English-speaking scholars. On the incoherence of all these rosters, see Yoshiro Miwa \& J. Mark Ramseyer, The Fable of the Keiretsu, 11 J. Econ. \& Mgmt. Strategy 169 (2002).

26 Hoshi et al., The Role of Banks, supra note 15, at 77. 
arrangements at all. Because the arrangements would invite such obvious adverse-selection and moral-hazard problems, basic logic suggests firms and banks would avoid them studiously. Yet according to the literature, in Japan they (at least the large firms) maintain them almost uniformly.

\section{EXAMPLeS}

\section{A. Introduction}

At the firm level, the data at least suggest that Japanese banks do not necessarily try to save all large troubled firms. If they do not try to save $e x$ post, of course, they cannot credibly (albeit implicitly) promise to save ex ante. More generally, the examples below suggest that Japanese banks and firms neither suppress conflicts of interest nor ignore them. Instead, exactly as micro-theory implies, they routinely find their options upon insolvency constrained by severe conflicts of interest.

Take several troubled firms in the $1970 \mathrm{~s} .{ }^{27}$ We suspect that readers will find their travails depressingly familiar. That familiarity, however, is the point: the very conflicts of interest that plague banks and troubled firms in the West plague banks and firms in Japan, cause the same problems, and induce participants to adopt much the same strategies.

\section{B. Mazda}

Thanks to the tale Pascale \& Rohlen told twenty years ago, ${ }^{28}$ Mazda has served as the poster child of Japanese bank rescues ever since. As they told it, the firm entered the 1970s with an iron-willed, engineering-obsessed, and somewhat pig-headed CEO from the original Matsuda family. Under his leadership, it invested heavily in rotary engines. Alas, when the OPECinduced price hikes hit in the middle of the decade, consumers abandoned the technologically flashy rotaries for the dowdy but more fuel-efficient piston engines from Toyota, Nissan, and Honda.

To turn Mazda around, the Sumitomo Bank stepped in as main bank.

27 The accounts are taken from the following periodicals: Ekonomisuto (Mar. 7, 1978; Mar. 18, 1978; Apr. 23, 1978; May 2, 1978; June 3, 1978; June 27, 1978); Shukan daiyamondo (Jan. 10, 1976); Nikkei bijinesu (Dec. 19, 1977); Chuo koron (Winter 1978: Spec. Mgmt. Prob. Issue); Toyo keizai (June 8, 1974; May 13, 1978; May 27, 1978; Nov. 4, 1978; Feb. 24, 1979; Apr. 20, 1979), and relevant securities filings.

28 Richard Pascale \& Thomas P. Rohlen, The Mazda Turnaround, 9 J. Japanese Stud. 219 (1983) 
It sent personnel, loaned money, repositioned the product line, enforced austerity - and saved the firm. In improving the firm's cash flow during this "rescue stage," write Pascale \& Rohlen, the Sumitomo Bank "played the pivotal role ..., its bold action virtually guaranteeing the company's debts."29

Yet the way Mazda reacted to the bank belies the notion that they implicitly agreed that the bank would rescue the firm. Had they cut such a deal ex ante, the bank should not have faced the resistance it did ex post. In fact, as Pascale \& Rohlen acknowledge, the firm fought the bank at every turn with its managers referring to the new arrivals as the "occupying army." 30

Under pressure in December 1974, Mazda accepted several outsiders to its thirty-member board. Other than one local banker appointed in 1967, it had not named bankers to its board for years. In time, however, it would name outside directors from a variety of sources. They would come not just from the Sumitomo Bank, but also from the Sumitomo Trust Bank, two local banks, and the trading companies with which Mazda dealt.

Although Mazda named a Sumitomo Bank representative vice-president in early 1976, it was late 1977 before the outsiders could oust the pig-headed Matsuda as CEO. When they did, they did not fire him or install a banker in his stead. Instead, the firm named him Chairman of the Board and replaced him with its incumbent third-in-command, a long-term Mazda engineer. By 1978, Mazda still had only four banker directors.

To keep Mazda viable, several entities provided crucial support. The Sumitomo Bank and Sumitomo Trust Bank both sent money. In November of 1979, Ford took a 25\% equity interest. The director from the Trust Bank directed capital budgeting issues; one director from the Sumitomo Bank managed exports while another directed accounting and cost-controls; the director from the C. Itoh trading firm coordinated sales; and the director from Sumitomo Trading took charge of managerial consolidation.

Pascale \& Rohlen characterize the story as a bank rescue, but one should wonder. The Sumitomo Bank never had the stake in Mazda that ordinarily would induce anyone to invest large resources in saving a firm. Although it had lent more to Mazda than anyone else, it had long kept its loan share modest: $13.6 \%$ in October 1974 and $14.5 \%$ in October 1977. Indeed, by October 1977 it was cutting its loans to Mazda: from 53.6 billion yen in October 1976 to 46.1 billion in October 1977, and by October 1980 to 26.3 billion. As of 1974 (and still in 1977) it held less than 4\% of the stock. Had

29 Id. at 257

$30 I d$. at $233,236$. 
it wanted to own more, it legally could have bought up to $10 \% \cdot{ }^{31}$ Instead, it kept its share below $4 \%$ and below that of the Nippon Life Insurance firm.

In fact, the Sumitomo Bank did not rescue Mazda. Instead, the entities with the greatest stakes in the firm collectively rescued it. None of them knew how to make cars, of course, but Mazda's problems did not lie in automotive engineering. Instead, they lay in financial management and marketing. Banks do know how to balance books, and trading companies know how to read consumer preferences and cultivate export markets. What Mazda needed these others could contribute. They did, and Mazda survived. Pascale \& Rohlen characterize the operation as Sumitomo-Bank-led — but probably only because they began their inquiry by looking for that bank leadership. ${ }^{32}$

\section{Eidai Industries}

Although Mazda still makes cars, troubled firms do not always survive. Sometimes, banks and trading partners intervene and fail. Eidai Industries mass-produced pre-fabricated housing and, by the 1970s, listed its stock on Section 1 of the Tokyo Stock Exchange. In the mid-1970s it found itself outcompeted. Outmaneuvered by its rivals, in December 1975 it posted a large loss.

Eidai's banks had known of its travails already by late 1974. To resolve those problems, in the fall of 1975 the largest five creditors agreed collectively to lend it more and to excuse it from its 2 billion yen semi-annual interest payment. True to their word, they lent large amounts. From 1971 to 1977, they increased their loans to Eidai from 7.5 billion yen to 75.3 billion (see Table 1 below).

The banks took a variety of other steps besides. They enlisted the participation of two trading firms that handled Eidai accounts. They encouraged Eidai to increase its sales force. They introduced clients to Eidai branches. They placed three bankers on Eidai's eleven-member board. They replaced the Eidai president, first with a former president of a DaiwaBank-affiliated securities firm, then with the number-four man at Daiwa itself.

31 At the time, antitrust legislation limited shareholdings by financial firms to $10 \%$. In 1977, that ceiling was lowered to 5\%, effective 1978.

32 Probably for much the same reason, Pascale \& Rohlen attribute "a key role" to government bureaucrats, when in fact the government did virtually nothing. Id. at 231. Indeed, even they acknowledge that "[a]ll company officials interviewed denied any government involvement." Id. 
But monitoring a borrower effectively is hard. If its rivals outcompeted Eidai, Eidai outfoxed its banks. The second Daiwa-sent president had planned to rebuild Eidai within two years. It was not to be. Despite having had three bankers on its board and a banker in its vice-presidential post even before the crisis, despite eventually accepting its president and fourteen other senior executives from the Daiwa Bank - despite all this, Eidai carried problems that went much deeper than any bank realized. By 1978, one year after the ambitious second Daiwa-sent president took office, the banks petitioned the court for its reorganization. "Banks know they're easy to fool," a senior Daiwa executive recalled, "but they got fooled again anyway." 33

Table 1: Loans and Loan Shares to Eidai Industries

\begin{tabular}{lrrrrrrr} 
& 1971 & 1972 & 1973 & 1974 & 1975 & 1976 & 1977 \\
\hline A. Loan share (\%): & & & & & & & \\
\cline { 2 - 3 } & 18.0 & 10.6 & 12.4 & 18.0 & 21.9 & 27.8 & 33.8 \\
Mitsubishi Trust & 10.3 & 10.4 & 10.1 & 12.6 & 12.0 & 12.2 & 11.9 \\
DKB & 6.7 & 6.6 & 5.9 & 6.4 & 6.8 & 7.3 & 7.9 \\
Bank of Tokyo & 2.6 & 7.3 & 8.6 & 11.1 & 11.8 & 16.5 & 21.4 \\
Fuji Bank & 1.0 & 5.6 & 8.0 & 7.7 & 7.7 & 7.6 & 8.7 \\
Total of top 5 & 38.7 & 40.5 & 45.1 & 55.8 & 60.2 & 71.3 & 83.7 \\
B. Total Loans (billion yen): & & & & & & \\
\hline
\end{tabular}

Source: Yoshiro Miwa, Firms and Industrial Organization in Japan 114 (1996).

Notes: Figures are for the end of December of each year.

\section{Sasebo Heavy Industries}

When a rescue occurs and a firm survives, sometimes it survives only by happenstance. During the 1960s and early 1970s, the Sasebo Heavy Industries ("SHI") shipbuilding firm had thrived. What with the explosive economic growth and the increasing need for large tankers, demand had boomed. Come 1977, however, the Arab oil embargo and the massive revaluation of the yen (from 290.3 yen/\$ in January 1977 to 195.4 in December 1978) had turned the boom into a bust. With total industry

33 Special Management Problems Issue, Chuo koron, Winter 1978, at 334. 
shipbuilding capacity of 19 million tons, Japanese firms had 1977 orders of only 5 million. At least the largest shipbuilding firms had diversified their product lines. Medium-sized SHI had not. By the fall of 1978, it had no orders at all.

Like most substantial Japanese firms, SHI borrowed broadly. From over a dozen banks, it had borrowed (as of March 1977) over 79.7 billion yen. Among the commercial banks, it had borrowed the most from the Daiichi Kangyo Bank ("DKB"): 3.3 billion yen. It had four major shareholders: the Kurushima dry-docks firm (25.0\%); the Nippon Kokan ("NKK") steel firm (24.2\%); Nippon Steel (14.1\%); and the Nissho Iwai trading firm (10.1\%). Kurushima had bought its interest because its CEO Toshio Tsubouchi wanted to integrate SHI's large dock facility into Kurushima. When he had earlier tried to become president, however, NKK had blocked his move and, instead, engineered the appointment of its own representative.

To deal with the non-existent demand, in early 1978, SHI asked for early retirements. By April, 1600 employees had volunteered, but to finance their retirement package, the firm needed 8.2 billion yen. It also would have to finance other changes, of course, and all told could expect to need about 20 billion yen. When it approached its banks, they balked.

Rather than volunteer the money, the banks told SHI to file for bankruptcy. At least on much of its debt, they held security interests. If the firm filed for bankruptcy immediately, they could expect some repayment. If they now loaned funds unsecured (and the firm apparently had no more assets to post), rather than repayment they could expect a steady stream of requests for yet more funds. The additional funds they loaned would effectively become hostage and lock them into future demands indefinitely.

The banks offered to lend the money only if SHI's lead shareholders would guarantee the debt, but the shareholders would not guarantee. NKK controlled SHI, and Tsubouchi - bitter still about the way NKK had blocked him from becoming president - was not about to guarantee any loans suggested by its handpicked managerial team. Absent a co-guarantee from Kurushima, neither would NKK guarantee a loan. And if Tsubouchi and NKK would not guarantee, Nippon Steel and Nissho Iwai would not do so either.

In short, neither the firm's creditors nor its shareholders would invest anything more in the firm. Ordinarily, such a firm would promptly go bankrupt. It did not, but only because SHI dominated the city of Sasebo and Prime Minister Takeo Fukuda owed the city a massive political debt. When the government's nuclear-powered ship Mutsu had developed a radioactive leak in 1974, all other ports had refused to take it. With a leaking nuclear ship sitting off the Japanese coast and nowhere to send it, Fukuda faced a political disaster. He averted it, but only when Sasebo agreed to take the ship. 
For that favor Fukuda now intervened personally. He struggled mightily to accomplish anything at all. Repeatedly, he urged the banks to fund SHI. Repeatedly, they refused. They would not loan the money unsecured and unguaranteed, they declared, and the firm could not secure and the shareholders would not guarantee.

Tsubouchi eventually did gain control, and SHI did survive, but it survived largely without banks and only on a reduced scale. From 79.7 billion yen in March 1977, by 1979 it had cut its debt to 51.1 billion, by 1981 to 38.7 billion, and by 1983 to 10.2 billion. From 6968 employees in 1977, by 1979 it had cut its workforce to 4223, by 1981 to 3422, and by 1983 to 2760 .

\section{E. Other Cases}

\section{Hanasaki}

Other distressed firms - even big firms - expeditiously go out of business. In the early 1970s, with its forty-year history, the venerable Hanasaki firm was one of the largest Japanese manufacturers of women's clothing. When it tried to expand in 1976, it found itself with enormous unsold inventory: 1.6 to 1.7 billion yen on annual sales of 18.5 billion.

"We begged it several times to come up with a consolidated rationalization plan, and a plan to rebuild," recalled one Sumitomo Bank representative. ${ }^{34}$ "But it wouldn't comply." So, when in October it saw Hanasaki's winter clothes moving slowly, the bank offset 200 million yen's worth of Hanasaki liabilities against Hanasaki's deposits. Early the next year it announced that "there are limits to a bank's assistance" and declared an end to all further loans. Promptly, Hanasaki went out of business.

\section{Hayashi Spinning}

Sometimes a rescue succeeds, but only after creditors manipulate the bankruptcy process to oust the incumbents. The Hayashi firm had been one of the largest wool spinning firms in Japan. When business worsened in 1977, the founder-president resigned. As his family had earlier pledged their stock in Hayashi Spinning to the Tokai Bank in exchange for its aid, they now sued to retrieve that stock.

Soon, rumors began to circulate that the family would liquidate the firm at the February shareholders meeting. Apparently, they planned to use their equity stake to demand concessions from their creditors. Afraid of losing

34 Apareru sangyo "shissoku" [Apparel Industry Nose Dives], Shukan toyo keizai, May 13,1978 , at 80. 
control, the Tokai Bank immediately filed for reorganization under the bankruptcy laws. Through the bankruptcy proceeding, the bank was able to cut the incumbent shareholders' interests to less than $10 \%$ of the firm's stock. It then reorganized and revamped the firm. The factories continued to operate with the labor force uncut — but now under bank control.

\section{Mitsumi Electrical}

And sometimes if banks try to intervene, the firms reject the banks and restructure on their own. Electrical-parts maker Mitsumi had fallen on hard times in 1970 after issuing bearer securities in Germany the previous year. In 1971 the Mitsui Bank ${ }^{35}$ sent in one of its men as Mitsumi vice-president and another as director - this in addition to the Mitsui banker already on the tenmember board. As of early 1970, the Mitsui Bank, Mitsumi's fourth-largest creditor, had lent Mitsumi 340 million yen. By 1972 it was its largest creditor and had 635 million yen outstanding.

Within a year the Mitsui officers had largely disappeared. The vicepresident had become an ordinary director, and the other directors had vanished. Apparently, the incumbent managers - still under the control of an autocratic CEO - had fought the bankers and pushed them out. Where Mitsumi had had 3528 employees in January 1971, three years later it was down to 2002 employees. It survived, but for several years only on a much reduced scale.

\section{EMPIRICS}

Nothing about these accounts will surprise readers, except perhaps the fact that they concern Japan. The tales hinge on predictable conflicts of interest among creditors, shareholders, and managers, and those participants respond to the predictable conflicts in predictable ways. Japanese banks and firms, the tales imply, behave by the same logic as banks and firms in the West. Yet anecdotes never end debates, and to explore more fully the role of conflicts of interest in Japanese business we turn to more systematic evidence.

\section{A. Data}

We use two lists of troubled firms. Our first roster (the 1978 firms) dates from the mid-1970s. As the examples above suggest, for Japan these were

35 The similarity in names is coincidental. Mitsui and Mitsumi are not related. 
badly troubled years. The 1974 oil crisis had thrown a steadily and rapidly growing economy into recession, and by 1978, a wide variety of firms were under water. For this list, we take all 320 exchange-listed firms with a loss carryforward in 1978. We obtain the list from the April 1978 issue of the monthly journal Toyo keizai tokei geppo. None of the firms was in the financial services industry.

Our second list (the 1984 firms) dates from the first half of the next decade. As the massive late-1980s boom illustrates, these were healthier times for the economy as a whole. Nonetheless, the health was not uniform. Troubled firms remained, and for this second list, we take all 134 exchange-listed non-financial firms with at least three consecutive loss years (after interest but before extraordinary gains and losses) as of April 1984. We obtain the list from the August 11,1984, issue of the weekly magazine Shukan toyo keizai.

The Japanese government gradually deregulated aspects of the financial services industry in the late 1980s. Some observers argue that this radically changed the "main bank system." In fact, as we show elsewhere, it did not. Because the regulations involved had not constrained bank-firm lending even in the $1960 \mathrm{~s},{ }^{36}$ their relaxation could not have significantly affected loan patterns. For our purposes, however, note that the 1978 dataset antedates any deregulation-induced changes to the system, and even the 1984 list antedated most of the changes.

We use the basic financial information that appears in the cited issues of the Toyo keizai tokei geppo and Shukan toyo keizai. We add board composition from the annual Kigyo keiretsu soran volume and stock price data from Toyo keizai kabuka CD-ROM database. Given both that the two lists represent different variations on financial distress and that the two journals provide different information on the firms, we switch between the two datasets as necessary.

As of 1978, there were 1584 exchange-listed firms in Japan. As of 1984, there were 1646.

\section{B. Variables}

For our regressions, we define the following variables. We include selected summary statistics in Table 2, below:

36 Miwa \& Ramseyer, supra note 6; Miwa \& Ramseyer, Financial Malaise, supra note 2; Miwa \& Ramseyer, Relationship Banking, supra note 2. 
Main Bank Loan Share: the fraction (in percent) of a firm's total bank loans borrowed from the bank lending the greatest amount to the firm.

Main Bank Experience Director: if followed by "no.," the number of directors at the firm with experience working at the bank lending the greatest amount to the firm; if followed by "dum.," a dummy variable equal to 1 if the firm has any such directors. ${ }^{37}$

Any Bank Experience Director: if followed by "no.," the number of directors at the firm with experience working at any bank; if followed by "dum.," a dummy variable equal to 1 if the firm has any such directors.

Dominant Shareholder: a dummy variable equal to 1 if any shareholder holds $25 \%$ or more of the firm's stock.

Total Bank Loans: the amount of a firm's bank loans, in million yen.

Total Main Bank Loans: the amount of a firm's loans from the bank lending the greatest amount to the firm, in million yen.

Table 2: Selected Summary Statistics

\begin{tabular}{|c|c|c|c|c|c|}
\hline & & $\mathrm{n}$ & Min. & Mean & Max. \\
\hline \multirow[t]{6}{*}{ A. } & 1978 Troubled Firms: & & & & \\
\hline & MB Loan Share 77 & 324 & 1 & 24.710 & 91.9 \\
\hline & MB Exper Director 78 & 323 & 0 & .703 & 7 \\
\hline & Any Bank Exper Dir 78 & 323 & 0 & 1.217 & 7 \\
\hline & Dominant $\mathrm{S} / \mathrm{h} 78$ & 323 & 0 & .390 & 1 \\
\hline & Total Bank Loans 77 & 320 & 28 & 18559 & 236671 \\
\hline \multirow[t]{6}{*}{ B. } & 1984 Troubled Firms: & & & & \\
\hline & MB Loan Share 84 & 129 & 5.794 & 28.736 & 100 \\
\hline & MB Exper Director 84 & 131 & 0 & .855 & 4 \\
\hline & Any Bank Exper Dir 84 & 131 & 0 & 1.489 & 9 \\
\hline & Dominant $\mathrm{S} / \mathrm{h} 84$ & 131 & 0 & .389 & 1 \\
\hline & Total Bank Loans 84 & 131 & 0 & 39775 & 509676 \\
\hline
\end{tabular}

Sources: Toyo keizai tokei geppo, Apr. 1978; Shukan toyo keizai, Aug. 11, 1984; Kigyo keiretsu soran [Firm Keiretsu Overview] (Toyo keizai ed., as updated).

37 For details on the determination of board composition, see Miwa \& Ramseyer, Outside Directors, supra note 2; Miwa \& Ramseyer, Relationship Banking, supra note 2. 


\section{Preliminary Observations}

\section{Industry Mix}

The firms in the two lists represent a variety of industries. The 3241978 firms most commonly came from the machinery industry - 14.8\% (48 firms). The textile industry followed with $13.6 \%$ (44 firms); the chemical industry with $9.0 \%$ (29 firms); and the steel industry with $8.6 \%$ (28 firms). Of the 1584 total listed firms that year, $10.3 \%$ were in machinery, $5.4 \%$ in textiles, $10.4 \%$ in chemicals, and $4.0 \%$ in steel.

By 1984, the industry mix had shifted a bit, but only a bit. Of the 134 troubled 1984 firms, $15.7 \%$ were in textiles ( 21 firms). The trading industry followed with $13.4 \%$ (18 firms); steel with $12.7 \%$ (17 firms); and chemicals with $11.9 \%$ (16 firms). Seventy of these firms had suffered three consecutive loss years; 26 firms had had four; and 38 firms had had five or more.

\section{1984 Firms: Subsequent Performance}

As a crude measure (we make no adjustments for stock splits or dividends) of how the market gauged the performance of troubled firms, consider the stock price of the 1984 firms. More specifically, consider the stock price trajectory of the 1011984 troubled firms that survived to 2001. ${ }^{38}$ In Figure 1, below, we partition our 1984 database into those firms whose stock traded above the group median in 1984 and those those stock traded below. We then index prices at $1984=100$ and compare the average price of the two groups of firms with that of the market index ("TOPIX"). According to the Figure, the below-average firms began to lag the market in the early 1970s. Although both groups of firms continued broadly to track the market as a whole, the lowest performers initially recovered after 1984 - doing well during the so-called "bubble economy" of the late 1980s. Their recovery did not last. By the end of the century, both groups underperformed TOPIX.

To gauge the performance of these firms (indexed again at 1984=100) more readily against the market index, in Figure 2, below, we reset TOPIX at 100 for each year and calculate the distance between the index and the stock prices of the two groups. The Figure conveys two simple messages. First, the market did not expect anyone to rescue these firms. Erratically to be sure, they underperformed the market from 1970 to 1984 . Recall that they had suffered at least three consecutive loss years by 1984. If the market

38 As of late 2001, one, Koma Stadium, had a stock price in the 8800 yen range (the price of the others totaled 14,733), so we exclude it from our database. 
had expected someone to rescue them, their stock would not steadily have underperformed the index. In fact, it did underperform the index.

Second, the market was right: no one did rescue them. ${ }^{39}$ Even after 1984, these firms continued to underperform. Their main banks did not rescue them, even though they took more directors from their main bank than other large firms: among large TSE firms as a whole, the mean firm appointed .67 directors from its main bank $;{ }^{40}$ among the troubled 1984 firms, the mean firm appointed .88 . Neither did their dominant shareholders rescue them, even though they tended to have such shareholders: among large TSE firms, $20 \%$ had a dominant shareholder; among the troubled 1984 firms, $37 \%$ did.

\section{Figure 1: Firms Partitioned by 1984 Stock Prices, with Market Index, $1984=100$}

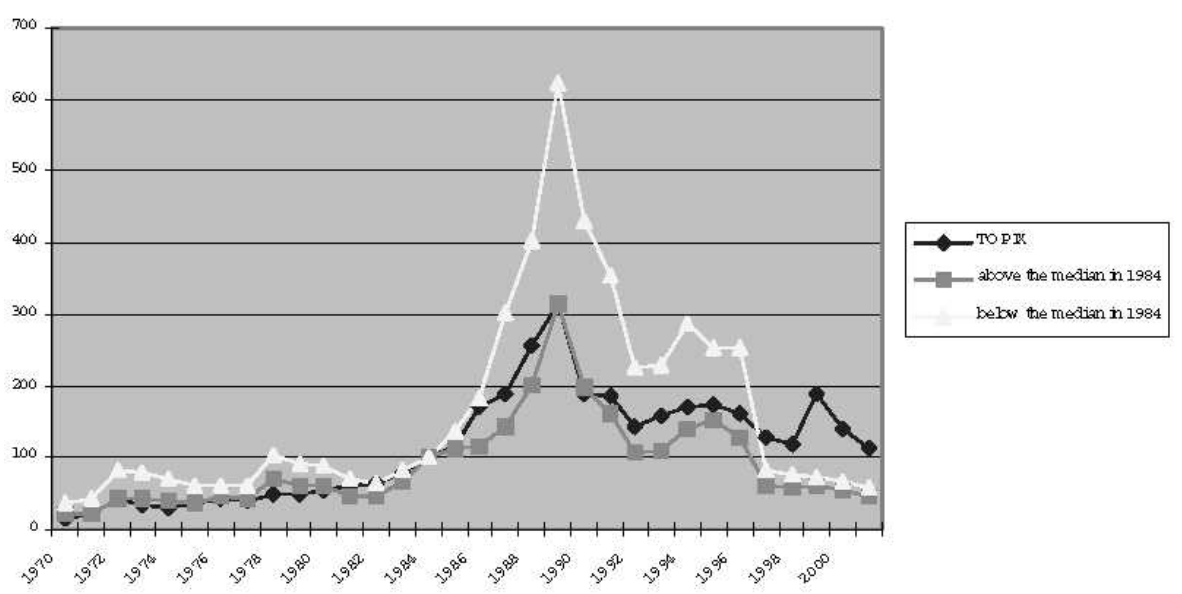

Notes: Firms are those in the 1984 database, as described in the text. They are partitioned by whether they were above or below the median stock price in 1984 for the group still listed in 2001. The Figure gives the mean price for the firms in the group as of the end of each year, indexed at $1984=100$.

39 Though their continued fall against the index is a puzzle - and a phenomenon one would not expect in a rational market.

40 Among the approximately 1000 firms trading on Section 1 of the TSE in 1985. 
Figure 2: Firms Partitioned by 1984 Stock Prices, Movement Relative to Market Index

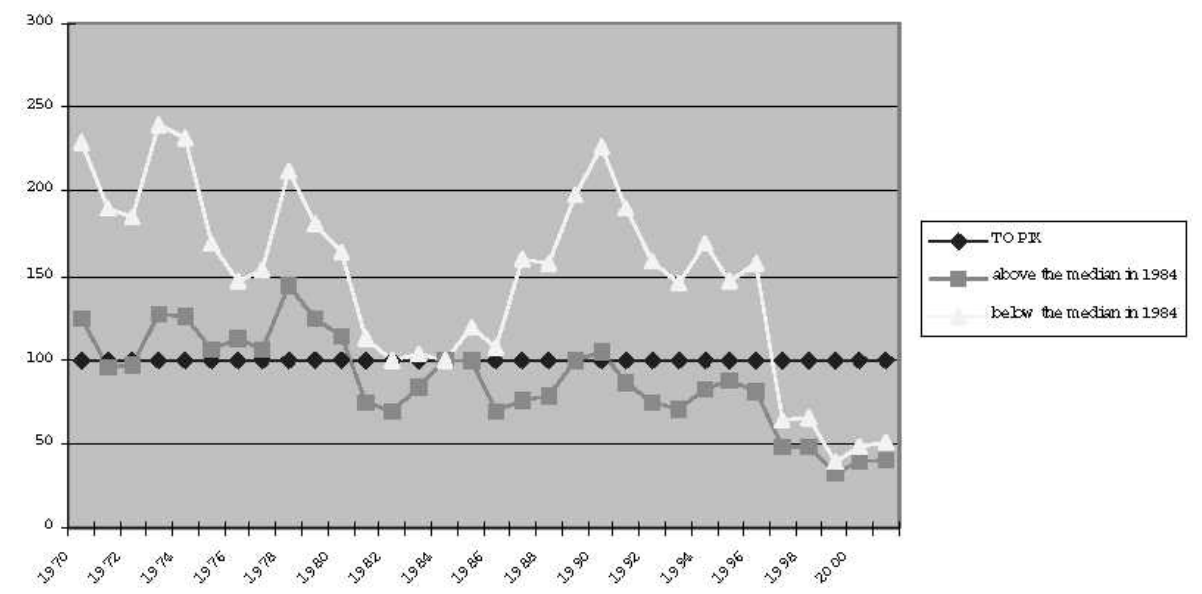

Notes: Firms are those in the 1984 database, as described in the text. They are partitioned by whether they were above or below the median stock price in 1984 for the group still listed in 2001. The Figure takes the stock price of the two groups of firms, indexes it at $1984=100$, and then calculates the distance between that price and the indexed TOPIX (here, shown at 100 for each year).

\section{1978 Firms: Composition}

To illustrate several closely related points, in Figures 3 and 4, below, we turn to our database of 1978 troubled firms and partition it by several variables. In Figure 3, we catalog the firms, first, by whether they were insolvent, then, by whether they had a dominant shareholder and whether they had any directors from their main bank. Finally, we give the number of firms in each category that disappeared by or survived to 1990 . Of the 324 firms in our sample, for instance, 87 were insolvent in 1978, and among those 87 firms, 43 had a dominant shareholder. Of those 43 , thirteen had a director from their main bank, and of the thirteen firms, six survived to 1990, while seven disappeared. In Figure 4, we similarly partition the database by whether the firms had a dominant shareholder, whether they changed their main bank affiliation during the preceding three years, whether they disappeared by 1990, and whether they were insolvent in 1978.

Two points stand out. First, neither dominant shareholders nor main bank directors necessarily keep firms solvent. Like the 1984 firms, many of the insolvent 1978 firms had a dominant shareholder (43 of the 87 firms) and many had directors from their main bank (35 of the firms). Second, neither such shareholders nor such directors necessarily keep troubled firms alive. Of the 64 firms that disappeared by 1990, 31 had had a dominant shareholder and 30 had had a main bank director. 
For reference, in Table 3 (below) we add loan information about several of the groups of partitioned firms. We give the partitioning along the left-hand column. We then follow that with the number of firms in each group; with the mean per firm loan amount (in millions of yen) in 1974; with the fractional increase to 1977; with analogous information on the mean per firm loans from each firm's main bank; and with the mean share of loans each firm obtains from its main bank.

Whatever story the data tell, they do not tell a story about main bank rescues. Granted, the main banks did lend to troubled firms. From 1974 to 1979 , they increased their loans to the solvent firms by $59 \%$, but to the insolvent by $87 \%$. Yet they increased the loans less than the other banks did. During the same period, the main banks' loan share at the solvent firms rose by $1 \%$, while at the insolvent firms it fell. What is more, by lending, the main banks did not save. Among the insolvent firms, the main banks increased their loans to the firms that survived by $66 \%$. To the firms that disappeared by 1990 , they increased their loans by $116 \%$.

\section{Figure 3: Composition of 1978 Database by Solvency}

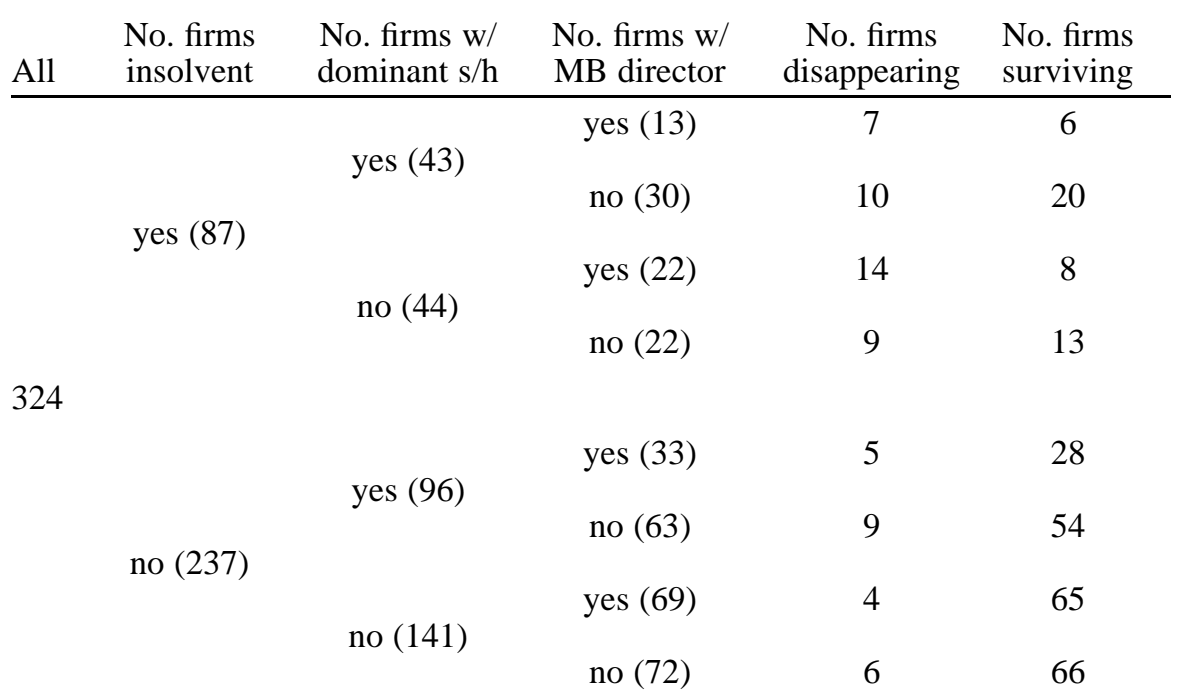

Sources: Toyo keizai tokei geppo, Apr. 1978; Shukan toyo keizai, Aug. 11, 1984; Kigyo keiretsu soran [Firm Keiretsu Overview] (Toyo keizai ed., as updated).

Notes: 1978 troubled firms, partitioned by whether they were insolvent, had a dominant shareholder, had a main bank director, and disappeared by or survived to 1990 . 
Figure 4: Composition of 1978 Database by Presence of Dominant Shareholder

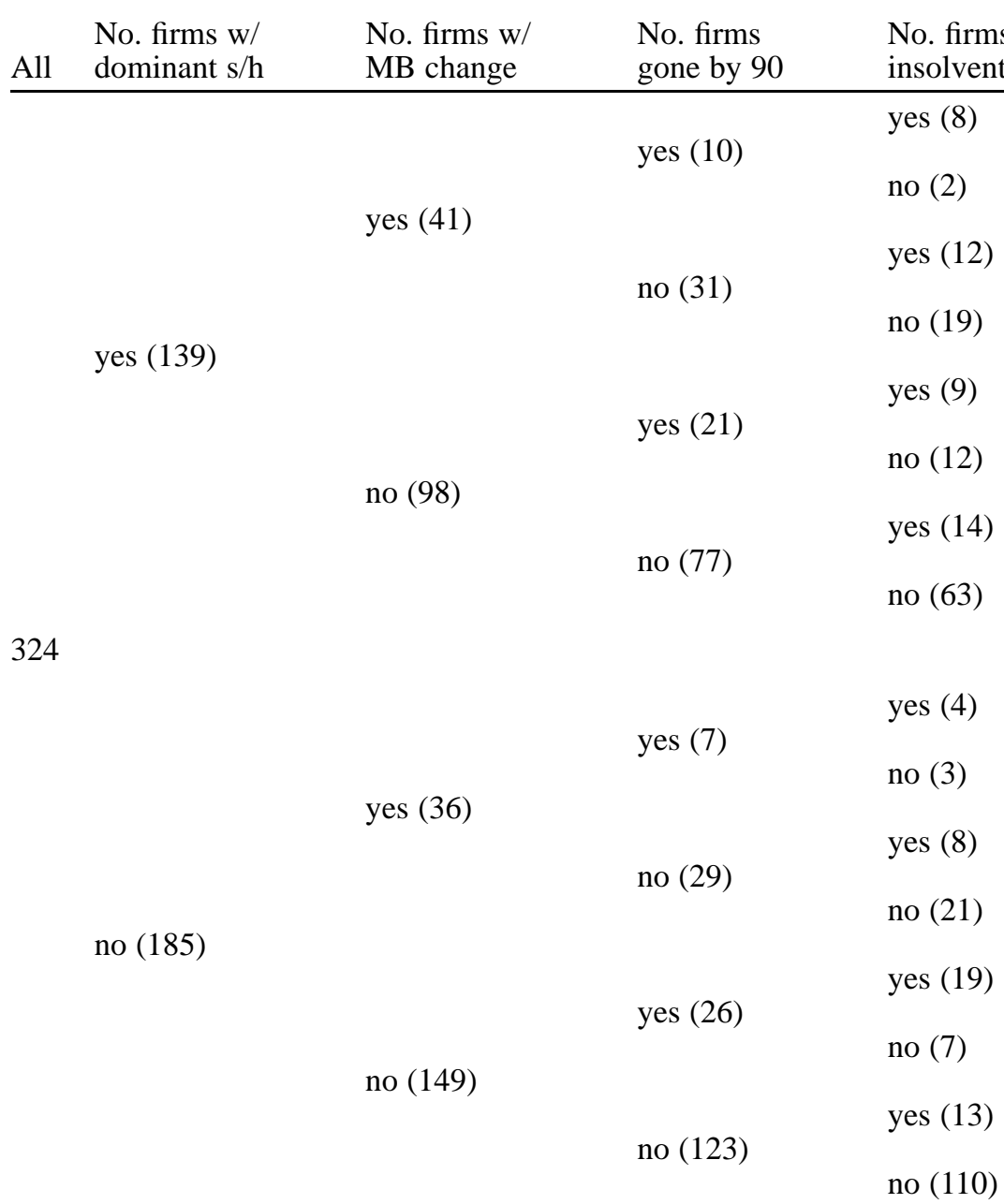

Sources: Toyo keizai tokei geppo, Apr. 1978; Shukan toyo keizai, Aug. 11, 1984; Kigyo keiretsu soran [Firm Keiretsu Overview] (Toyo keizai ed., as updated).

Notes: 1978 troubled firms, partitioned by whether they had a dominant shareholder, had changed their main bank affiliation during the three preceding years, disappeared by 1990, and were insolvent in 1978 . 
Table 3: Loans to Firms in 1978 Data Base

\begin{tabular}{|c|c|c|c|c|c|c|c|c|}
\hline & $\begin{array}{l}\text { No. } \\
\text { Firms }\end{array}$ & $\begin{array}{l}74 \text { Tot } \\
\text { Loan(*) }\end{array}$ & $\begin{array}{l}77 \text { Tot Ln } \\
\text { Indexed(**) }\end{array}$ & $\begin{array}{l}74 \mathrm{MB} \\
\text { Loan }\end{array}$ & $\begin{array}{r}77 \text { MB Ln. } \\
\text { Indexed }\end{array}$ & $\begin{array}{l}74 \text { Loan } \\
\text { Share(A) }\end{array}$ & $\begin{array}{l}77 \text { Loan } \\
\text { Share(B) }\end{array}$ & A-B \\
\hline all & 324 & 13,295 & 140 & 2,223 & 164 & 24.2 & 24.7 & 0.5 \\
\hline Insolvent & 87 & 6,915 & 149 & 1,439 & 187 & 27.4 & 26.5 & -0.9 \\
\hline Had Dominant S/h in 1975 & 43 & 5,018 & 159 & 968 & 175 & 24.8 & 19.9 & -4.9 \\
\hline Had MB Exper. Director & 13 & 7,267 & 134 & 1,699 & 196 & 29.4 & 30.1 & 0.7 \\
\hline No MB Exper. Director & 30 & 4,009 & 179 & 641 & 153 & 22.7 & 15.4 & -7.3 \\
\hline No Dominant S/h in 1975 & 44 & 8,726 & 143 & 1,889 & 195 & 29.9 & 32.9 & 3.0 \\
\hline Had MB Exper. Director & 22 & 10,693 & 138 & 2,442 & 180 & 31.8 & 38.8 & 7.0 \\
\hline No MB Exper. Director & 22 & 6,759 & 152 & 1,336 & 222 & 28.0 & 27.0 & -1.0 \\
\hline Solvent & 237 & 15,639 & 138 & 2,511 & 159 & 23.1 & 24.1 & 1.0 \\
\hline Had Dominant S/h in 1975 & 96 & 12,266 & 154 & 2,089 & 171 & 22.5 & 21.4 & -1.1 \\
\hline Had MB Exper. Director & 33 & 20,983 & 151 & 3,486 & 153 & 25.2 & 23.4 & -1.8 \\
\hline No MB Exper. Director & 63 & 7,700 & 159 & 1,357 & 194 & 21.0 & 20.3 & -0.7 \\
\hline No Dominant S/h in 1975 & 141 & 17,986 & 130 & 2,804 & 153 & 23.5 & 25.9 & 2.4 \\
\hline Had MB Exper. Director & 69 & 20,667 & 127 & 3,476 & 159 & 23.8 & 27.7 & 3.9 \\
\hline No MB Exper. Director & 72 & 15,455 & 135 & 2,170 & 144 & 23.2 & 24.2 & 1.0 \\
\hline Had MB Exper. Director & 137 & 17,829 & 135 & 3,139 & 162 & 26.0 & 28.7 & 2.7 \\
\hline Had MB change & 21 & 14,003 & 137 & 2,372 & 147 & 20.4 & 20.5 & 0.1 \\
\hline No MB change & 116 & 18,533 & 135 & 3,280 & 164 & 27.0 & 30.2 & 3.2 \\
\hline No MB Exper. Director & 187 & 9,986 & 145 & 1,554 & 167 & 23.0 & 21.8 & -1.2 \\
\hline MB change & 56 & 7,401 & 124 & 819 & 156 & 20.0 & 18.5 & -1.5 \\
\hline No MB change & 131 & 11,108 & 152 & 1,874 & 169 & 24.3 & 23.2 & -1.1 \\
\hline Insolvent & & & & & & & & \\
\hline $\begin{array}{l}\text { disappeared by } 1990 \\
\text { by } 1978\end{array}$ & $\begin{array}{l}40 \\
24\end{array}$ & $\begin{array}{l}5,776 \\
7,650\end{array}$ & $\begin{array}{l}165 \\
150\end{array}$ & $\begin{array}{l}1,352 \\
1,687\end{array}$ & $\begin{array}{l}216 \\
221\end{array}$ & $\begin{array}{l}30.6 \\
28.8\end{array}$ & $\begin{array}{l}31.5 \\
29.1\end{array}$ & $\begin{array}{l}0.9 \\
0.3\end{array}$ \\
\hline during 1978-1990 & 16 & 2,778 & 229 & 816 & 209 & 33.4 & 35.2 & 1.8 \\
\hline alive in 1990 & 47 & 7,860 & 139 & 1,512 & 166 & 24.7 & 22.2 & -2.5 \\
\hline Solvent & & & & & & & & \\
\hline disappeared by 1990 & 24 & 18,534 & 125 & 2,323 & 159 & 22.3 & 19.7 & -2.6 \\
\hline by 1978 & 9 & 22,977 & 129 & 3,093 & 186 & 23.0 & 20.5 & -2.5 \\
\hline in $1978-1990$ & 15 & 15,678 & 122 & 1,828 & 135 & 21.9 & 19.2 & -2.7 \\
\hline alive in 1990 & 213 & 15,324 & 140 & 2,531 & 159 & 23.2 & 24.6 & 1.4 \\
\hline MB change & 77 & 9,202 & 129 & 1,243 & 151 & 20.1 & 19.0 & -1.1 \\
\hline No MB change & 247 & 14,591 & 142 & 2,533 & 166 & 25.5 & 26.5 & 1.0 \\
\hline Had Dominant S/h in 1975 & 139 & 10,060 & 155 & 1,748 & 171 & 23.2 & 20.9 & -2.3 \\
\hline No Dominant $\mathbf{S} / \mathbf{h}$ in 1975 & 185 & 15,747 & 132 & 2,583 & 161 & 25.0 & 27.6 & 2.6 \\
\hline
\end{tabular}

(*) million yen

(**) $\quad 1974=100$ 


\section{Testable Hypotheses}

Nonetheless, according to most Japan "experts," main banks do implicitly agree to rescue troubled borrowers. Typically, the experts claim that the banks rescue by lending the firms funds they otherwise would not lend. Even when a loan is not otherwise financially advantageous, main banks lend.

From this, several testable implications follow:

a) Firm failures. Very few listed firms will fail. If all (or most) large firms have a main bank and main banks agree to rescue their distressed borrowers, then few large firms should disappear.

If (as occasionally claimed in the literature) the presence of directors from a firm's main bank (or the fraction of its loans from the main bank) proxies for the strength of the firm's ties with its main bank, then firms with more directors from their main bank (or borrowing more from their main bank) should be less likely to fail than other firms.

b) Main bank loan share. When financially troubled, firms will borrow heavily from their main bank. Banks do not all agree to rescue borrowers. Rather, only main banks do. If so, then the fraction of a firm's loans coming from the main bank should rise during times of financial distress.

If the presence of directors from a firm's main bank (or the fraction of its loans from the main bank) proxies for the strength of a distressed firm's ties with its main bank, then the fraction of a firm's loans coming from the main bank will rise most dramatically at firms with more directors from their main bank (or with a greater fraction of their loans from their main bank).

c) Total loans. Firms will continue to borrow during times of distress. Either the main bank will itself lend the troubled firm the funds it needs (the most common conventional hypothesis), or by implicitly guaranteeing the firm's debts, it will facilitate loans elsewhere (an occasional alternative hypothesis).

d) Main bank switch rates. The most troubled firms will rarely switch their main bank affiliation. Holding an implicit insurance contract from their main bank, the more seriously troubled firms will seldom abandon the relationship.

\section{Bank Rescues}

\section{Firm Failures}

Firms fail in Japan, even big exchange-listed firms. The notion that main banks save all large troubled firms is simply false. Of the troubled firms in $1978,10.3 \%$ vanished immediately and $20.9 \%$ had not recovered six years later: i.e., 33 firms disappeared within a year and 67 remained 
sufficiently underperforming to appear on the 1984 list. Of the firms that disappeared, 14 disappeared by merger, 9 through various bankruptcy-related legal proceedings, and 10 simply delisted (not all delisted firms failed, of course).

In Table 4, we explore some of the possible determinants of firm failure. Toward that end, we use the 1984 sample and regress on several variables a dummy variable equal to 1 if the firm was still listed on the TSE in late 2001. Because the conventional wisdom does not specify when strong main-bank ties most matter, we use as our independent variables not just (i) those from 1984 (col. 3), but (ii) those from the years before the onset of distress (1978 and 1981, cols. $1 \& 2$ ) and (iii) those from the years after the distress (1987, col. 4) as well.

According to the literature, the stronger a main bank's ties to a firm, the more likely the bank will save the firm. In fact, according to Table 4, the more a firm depended on its main bank for its debt in 1984 or 1987 (the higher was Main Bank Loan Share), the lower the odds that it would still exist in 2001. The number of potential main bank representatives on the firm's board (Main Bank Experience Director) and the presence of a dominant shareholder (Dominant Shareholder) had no observable relation to the odds that the firm would survive.

If main-bank-tied firms tended to disappear, might they have disappeared because the main bank "rescued" them through a merger? In Table 5, we take the disappeared firms and regress on the same variables a dummy variable equal to 1 if the firm was a party to a merger. Again, we compare the results obtained with independent variables from four separate years. Once more, the strength of a firm's ties to its main bank shows no observable connection to the possibility of merger. If main banks engineer mergers, it does not appear in the data.

In fact, the distinction between a liquidation and a merger is a distinction without substance anyway. On the one hand, that a firm is liquidated says nothing about what happens to its assets or employees. If its assets have economic value, another firm will buy and use them. If its employees have skills specific to those assets, then the firm that buys the assets will have an incentive to hire the employees as well. On the other hand, that a firm is merged likewise says nothing about what happens to its assets or employees. If the acquiring firm cannot use the merged firm's assets as productively as another firm could, it will sell them. If it does not find the merged firm's employees cost-effective, it will discharge them. Fundamentally, whether a firm is liquidated or merged says nothing about what happens either to its assets or to its employees. 
Table 4

Determinants of Survival: Probit Regression Results

\begin{tabular}{lcccc} 
& \multicolumn{4}{c}{ Dependent Variable: TSE Listed in 2001 } \\
& \multicolumn{4}{c}{ Independent Variables From - } \\
& 1978 & 1981 & 1984 & 1987 \\
\hline MB Loan Share & $-.010(1.17)$ & $-.014(1.71)$ & $-.015(2.22)$ & $-.024(3.04)$ \\
MB Exper. Director (no.) & $-.095(0.78)$ & $.141(1.16)$ & $-.060(0.54)$ & $-.116(0.74)$ \\
Dominant S/h & $-.118(0.44)$ & $.040(0.16)$ & $.079(0.29)$ & $-.118(0.44)$ \\
Total Bank Loans $\left(\mathrm{x} 10^{4}\right)$ & $-.025(1.31)$ & $-.030(2.15)$ & $.027(1.78)$ & $-.013(1.00)$ \\
Pseudo $\mathrm{R}^{2}$ & 0.03 & 0.04 & 0.06 & 0.00 \\
$\mathrm{n}$ & 131 & 132 & 129 & 121
\end{tabular}

Sources: Toyo keizai tokei geppo, Apr. 1978; Shukan toyo keizai, Aug. 11, 1984; Kigyo keiretsu soran [Firm Keiretsu Overview] (Toyo keizai ed., as updated).

Notes: The data set is the 1984 firms, as explained in the text. In each case, we give the coefficients, followed by the absolute value of the z-statistics (calculated with robust standard errors) in parentheses. The regressions include a constant term, not reported here.

\section{Table 5}

Determinants of Merger: Probit Regression Results Disappearing Firms Only

\begin{tabular}{lcccc} 
& \multicolumn{4}{c}{ Dependent Variable: Disappeared Through Merger } \\
& \multicolumn{4}{c}{ Independent Variables From - } \\
& 1978 & 1981 & 1984 & 1987 \\
\hline MB Loan Share & $.005(0.37)$ & $-.014(1.27)$ & $-.005(0.47)$ & $.018(1.13)$ \\
MB Exper. Director (no.) & $.636(1.37)$ & $.751(1.78)$ & $.433(1.46)$ & $-.289(0.50)$ \\
Dominant S/h & $1.200(1.74)$ & $1.341(1.80)$ & $1.272(1.64)$ & $.960(1.26)$ \\
Total Bank Loans $\left(\times 10^{4}\right)$ & $.060(1.71)$ & $.041(1.02)$ & $.033(1.22)$ & $.000(1.51)$ \\
Pseudo R & & & & 0.13 \\
$\mathrm{n}$ & 0.18 & 0.17 & 0.13 & 0.18 \\
& 32 & 33 & 29 & 20
\end{tabular}

Sources: Toyo keizai tokei geppo, Apr. 1978; Shukan toyo keizai, Aug. 11, 1984; Kigyo keiretsu soran [Firm Keiretsu Overview] (Toyo keizai ed., as updated).

Notes: The data set is the 1984 firms, as explained in the text. In each case, we give the coefficients, followed by the absolute value of the z-statistics (calculated with robust standard errors) in parentheses. The regressions include a constant term, not reported here. 
2. Main Bank Loan Share

a) 1978 firms. According to the conventional accounts, in implicitly agreeing to rescue troubled firms the main bank promises to lend the firms additional funds as necessary. By contrast, the 1978 data show no willingness on the part of the main banks to shoulder any substantial additional part of the loans to the troubled firms. In 1974, the main banks in the dataset had lent an average of $24.2 \%$ of the debt of the firms involved. By 1977, that fraction had risen - but only to $24.7 \%$.

Even that evidence misleads, for at the most seriously troubled 1978 firms, the main banks dramatically cut their exposure. Among the 324 troubled 1978 firms, 87 (26.9\%) were insolvent. From 1974 to 1977, the main banks reduced the amount they lent to 19 of the insolvent firms (21.8\%). They cut the fraction of the insolvent firms' loans they were willing to finance at 44 $(50.6 \%)$

b) 1984 firms. To see the phenomenon more clearly, consider Table 6, below. There, we trace the loan patterns at the firms in the 1984 dataset during the years before and after 1984. In the first line of each panel, we give the relevant figures for the dataset as a whole. In the next lines, we partition the dataset by the size of a firm's borrowings and include the relevant figures for each subset (see the notes to the Table for the partitioning standards). Largely for informational purposes, in Panel A we give the per-firm average total bank loans, in Panel B the per-firm average growth in bank loans, and in Panel $C$ the per-firm average main bank loans.

Note that the per-firm mean figures of Panels B and C will sometimes reflect outlying data points caused by events that have nothing to do with bank rescues. If a large firm merges with another, for example, it may increase the mean per-firm borrowing (as when Maruzen Oil merged with Daikyo Oil during the 1984-87 period - both were in the largest quartile). If a firm buys another firm and borrows heavily to build the new business, it may similarly increase the mean (as when the Daiei general merchandising store bought Maruko and expanded it into Daiei Finance during 1987-90).

In any event, consider Panel D, where we trace the change in the distribution of bank loans between the firms' main banks and the other banks. During the 1970s, these firms had borrowed $18 \%$ to $20 \%$ of their funds from their main banks. As they hit hard times in the early 1980s, the main banks cut the amounts they lent them. From 18.1\% in 1981, by 1983 and 1984 they reduced the amounts they shouldered to under $17 \%$. Only as the firms began to recover did the main banks increase the fraction again (and note the cautionary results in Table 8).

Or turn to Table 7, where we give the number of firms (partitioned by 
loan size as in Table 6) at which the main bank raised or cut the fraction of the firm's debt it shouldered. Focus on the most troubled period for these firms: 1981-84. Note that for the firms with the most outstanding debt, the main banks raised the share they financed at only 3 firms, but cut it at 10 . For the group with the second largest amount of debt, the main banks raised their share at 17 , but cut it at 23 . Only with the next smaller-debt group did they increase the share they financed more often than they cut it, but then only by 13 to 12 .

\section{Table 6: Bank Loans at the Troubled Firms}

A. Total bank loans (per firm average):

\begin{tabular}{lrrrrrrrr} 
& 1972 & 1978 & 1981 & 1983 & 1984 & 1987 & 1990 & 1996 \\
\hline All firms & 16182 & 32055 & 37876 & 41870 & 39775 & 40153 & 38972 & 48608 \\
$\begin{array}{l}\text { By amount of bank debt } \\
\text { Very large }\end{array}$ & 88730 & 191977 & 250569 & 271031 & 255853 & 266234 & 229873 & 273926 \\
Large & 14396 & 24914 & 24952 & 27497 & 26552 & 27088 & 25705 & 29946 \\
Small & 3528 & 6592 & 6224 & 7189 & 7202 & 10841 & 19069 & 35020 \\
Very small & 2096 & 3658 & 3021 & 2745 & 2562 & 3199 & 7008 & 10362
\end{tabular}

B. Per firm average growth in total bank loans $(100+\%)$ :

\begin{tabular}{|c|c|c|c|c|c|c|}
\hline & $1972-78$ & $1978-84$ & $1981-84$ & $1984-87$ & $1987-90$ & $1990-96$ \\
\hline All firms & 198 & 124 & 105 & 101 & 97 & 125 \\
\hline \multicolumn{7}{|c|}{ By amount of bank debt } \\
\hline Very large & 216 & 133 & 102 & 104 & 86 & 119 \\
\hline Large & 173 & 107 & 106 & 102 & 95 & 116 \\
\hline Small & 187 & 109 & 116 & 151 & 176 & 184 \\
\hline Very small & 175 & 70 & 85 & 125 & 219 & 148 \\
\hline
\end{tabular}

C. Total main bank loans (per firm average):

\begin{tabular}{lcccccccc} 
& 1972 & 1978 & 1981 & 1983 & 1984 & 1987 & 1990 & 1996 \\
\hline All firms & 3219 & 5823 & 6874 & 7056 & 6692 & 7351 & 8021 & 9955 \\
$\begin{array}{l}\text { By amount of bank debt } \\
\text { Very large }\end{array}$ & 12539 & 29394 & 39084 & 38514 & 36063 & 41613 & 43458 & 56535 \\
Large & 4440 & 5837 & 5906 & 5855 & 5561 & 6632 & 6092 & 6161 \\
Small & 1049 & 1563 & 1543 & 2015 & 2147 & 2335 & 2755 & 4952 \\
Very small & 508 & 967 & 891 & 979 & 943 & 1056 & 1523 & 2457 \\
& & & & & & & & \\
\end{tabular}


Table 6: Bank Loans at the Troubled Firms (cont.)

D. Main bank loan share (\%):

\begin{tabular}{|c|c|c|c|c|c|c|c|c|}
\hline & 1972 & 1978 & 1981 & 1983 & 1984 & 1987 & 1990 & 1996 \\
\hline All firms & 19.9 & 18.2 & 18.1 & 16.9 & 16.8 & 18.3 & 20.6 & 20.5 \\
\hline \multicolumn{9}{|c|}{ By amount of bank debt } \\
\hline Very large & 14.1 & 15.3 & 15.6 & 14.2 & 14.1 & 15.6 & 18.9 & 20.6 \\
\hline Large & 30.8 & 23.4 & 23.7 & 21.3 & 20.9 & 24.5 & 23.7 & 20.6 \\
\hline Small & 29.7 & 23.7 & 24.8 & 28.0 & 29.8 & 21.5 & 14.4 & 14.1 \\
\hline Very small & 24.2 & 26.4 & 29.5 & 35.7 & 36.8 & 33.0 & 21.7 & 23.7 \\
\hline
\end{tabular}

Sources: Toyo keizai tokei geppo, Apr. 1978; Shukan toyo keizai, Aug. 11, 1984; Kigyo keiretsu soran [Firm Keiretsu Overview] (Toyo keizai ed., as updated).

Notes:

* The firms are the 134 stock-exchange listed firms listed in the August 11, 1984, issue of Shukan toyo keizai as having had negative after-interest profits for three years in a row.

* Debt sizes: very large $=$ firms with over 100 billion yen in bank debt as of March 1984 (15 firms); large $=$ firms with 10-100 billion yen in bank debt $(40$ firms); small $=$ firms with $5-10$ billion yen in bank debt $(25$ firms); very small $=$ firms with less than 5 billion yen in bank debt (54 firms).

* The average main bank loan share is calculated from the group loan amounts as a whole, rather than as an average of the per firm loan shares.

Table 7: Number of Firms with Increase or Decrease in Main Bank Loan Share

\begin{tabular}{lcccccc} 
& $1972-78$ & $1978-81$ & $1981-84$ & $1984-87$ & $1987-90$ & $1990-96$ \\
\hline $\begin{array}{l}\text { VL group } \\
\quad \text { Increase }\end{array}$ & 6 & 8 & 3 & 10 & 9 & 8 \\
$\quad \begin{array}{l}\text { Unchanged } \\
\quad \text { Decrease }\end{array}$ & 9 & 7 & 10 & 3 & 4 & 4 \\
$\begin{array}{l}\text { L group } \\
\quad \text { Increase }\end{array}$ & 15 & 23 & 17 & 22 & 24 & 21 \\
$\quad$ Unchanged & 1 & 16 & 23 & 12 & 11 & 12 \\
$\quad \begin{array}{l}\text { Decrease } \\
\text { group }\end{array}$ & 22 & 14 & 13 & 12 & 12 & 14 \\
$\quad \begin{array}{l}\text { Increase } \\
\text { Unchanged }\end{array}$ & 9 & 11 & 12 & 9 & 9 & 5 \\
$\quad$ Decrease & 15 & & & & & (cont.)
\end{tabular}


Table 7: Number of Firms with Increase or Decrease in Main Bank Loan Share (cont.)

\begin{tabular}{lcccccc} 
& $1972-78$ & $1978-81$ & $1981-84$ & $1984-87$ & $1987-90$ & $1990-96$ \\
\hline VS group & & & & & & \\
Increase & 33 & 31 & 27 & 27 & 18 & 28 \\
Unchanged & & 2 & & 3 & 1 & 1 \\
Decrease & 14 & 15 & 22 & 19 & 30 & 18
\end{tabular}

Sources: Toyo keizai tokei geppo, Apr. 1978; Shukan toyo keizai, Aug. 11, 1984; Kigyo keiretsu soran [Firm Keiretsu Overview] (Toyo keizai ed., as updated).

Notes: The firms are the 134 stock-exchange listed firms listed in the August 11, 1984, issue of Shukan toyo keizai as having had negative after-interest profits for three years in a row.

The firms are partitioned by debt size: very large $=$ firms with over 100 billion yen in bank debt as of March 1984 (15 firms); large = firms with 10-100 billion yen in bank debt (40 firms); small $=$ firms with 5-10 billion yen in bank debt $(25$ firms $)$; very small $=$ firms with less than 5 billion yen in bank debt (54 firms).

For each cell, we give the number of firms where the change in Main Bank Loan Share increased, decreased, or remained unchanged during the period at issue.

c) OLS regressions. In Table 8, we use the 1984 data set to compare the factors that contribute to increases in the share of a firm's debt the main bank finances during the periods before and after distress. Unfortunately, the conventional literature does not specify when main-bank ties matter most. As a result, we use data from four separate time windows. In Panel A, we examine the period leading up to distress: we first use the increase in Main Bank Loan Share over 1981-84 as our dependent variable and independent variables from 1981 and then pair the increase over 1978-84 with independent variables from 1978. In Panel B, we examine the period after the distress: we take our independent variables from 1984 and use as our dependent variable first the Main Bank Loan Share increase over 1984-87 and then the increase over 1984-90.

For the first two columns of each panel of Table 8, we use as independent variables either (i) the number of directors with experience at the main bank or (ii) a dummy variable equal to 1 if the firm has any such director. For the last two columns, we use either (x) the number of directors with experience at any bank or (y) a dummy variable equal to 1 if the firm has any such director. Note that Main Bank Loan Share and Main Bank Experience Director are not strongly correlated. Among the 67 firms with no ex-main-bank directors in 1984, the average main bank loan share was $26.3 \%$, while among the 62 firms with at least one ex-main-bank director it was $31.4 \%$; the difference between the two means is not significant at even the $10 \%$ level (two-tailed 
test). The correlation coefficient between Main Bank Loan Share and Main

Bank Experience Director (no.) for 1984 is 0.11.

By 1984, the firms in our sample already would have experienced at least three consecutive loss years. A main bank that intended to rescue such a firm should have begun to lend it extra funds by then. For that reason, we focus on the years leading up to 1984 in Panel A of Table $8:{ }^{41}$ changes in a firm's Main Bank Loan Share during the three or more loss years and the years leading up to those years. Suppose, as often asserted, that (i) the share of a firm's debt a main bank finances and (ii) the number of directors from the main bank on a firm's board both proxy for the strength of the firm's ties to the main bank. Suppose further that bank rescues take the form of loans by a main bank to a troubled firm that other banks would not willingly make. If main banks rescue the troubled firms closest to them, then these hypotheses imply that a firm's Main Bank Loan Share and Main Bank Experience Director will be positively associated with increases in its Main Bank Loan Share as it enters troubled times.

According to Panel A, main banks do not rescue their troubled clients. The coefficients on Main Bank Loan Share are significantly negative for 1978-84 and insignificant for 1981-84. The coefficients on Main Bank Experience Director are uniformly insignificant. If anything, the closer the ties a firm maintains with its main bank, the more the bank will cut the share of the firm's debt it finances as the firm enters distress.

The results for Panel B present more of a puzzle. During the years after distress, the firm's Main Bank Loan Share continues to be negatively associated with increases in that variable: in all specifications, the greater the share of a firm's debt the main bank finances, the more it cuts that exposure during the years after distress. At first glance, however, the coefficient on Main Bank Experience Director seems to support the bank-rescue hypothesis: for both the 1984-87 and the 1984-90 periods, the coefficient is positive and weakly significant at the $10 \%$ level.

We say "at first glance" because the result appears neither statistically robust nor economically very large. Consider the first of the regression results using 1984-87 data. Statistically, the significance here of the Main Bank Experience Director variable hinges on the simultaneous inclusion of Main Bank Loan Share. If we drop the latter, the t-statistic on the

41 Additionally, note that, by 1984, Japanese asset prices had begun to boom, raising the value of mortgageable assets at most firms, lowering the default risk they presented - and reducing the implication that any loan to a firm represented a "rescue." Indeed, as Figure 1 shows, by 1984, the stock prices of the firms in this sample had already begun to rise. 
director variable drops to 0.71. By contrast, Main Bank Loan Share remains negative and significant regardless of whether we include Main Bank Experience Director. Even if we drop the latter, the t-statistic on the loan share variable stays at -2.64 .

Economically, the number of main bank directors has relatively little impact on the change in the main bank's loan share over 1984-87. By the conventional wisdom, a firm with close main bank ties would both borrow a higher fraction of its debt from its main bank (larger Main Bank Loan Share) and name more directors from its main bank (larger Main Bank Experience Director). Yet according to Panel B, the negative coefficient on loan share more than offsets the positive coefficient on the director variable.

To illustrate, compare a firm with median values for each of the relevant variables in 1984 with a firm with stronger-than-median ties to its main bank. The firm with median values for all variables would have found that its predicted Main Bank Loan Share (given in percent) increased during 1984-87 by 3.571 percentage points. ${ }^{42}$ Now suppose this firm had strongerthan-median main bank ties reflected in a 1984 Main Bank Experience Director value one standard deviation above the median. Over 1984-87, its predicted Main Bank Loan Share would have risen by an additional 2.121 points, for a predicted increase of $(3.571+2.121=) 5.692$.

By contrast, however, suppose that our otherwise-median firm instead had strong main bank ties reflected in a 1984 Main Bank Loan Share one standard deviation above the median. Over 1984-87, its Main Bank Loan Share shift would have lagged that of the median firm by 6.298 points. Because the median firm had a predicted increase in its Main Bank Loan Share of 3.571, our firm with strong main bank ties would have had a predicted 1984-87 fall of (3.571 - $6.298=)$-2.727.

Finally, suppose that our firm had strong main bank ties reflected in loan share and director values that both lay one standard deviation above the median. Because the negative effect of the loan share variable more than offsets the positive effect of the director variable, over 1984-87 this firm's Main Bank Loan Share would have lagged that of the median firm by $(6.298-2.121=) 4.177$. Given that the median firm had a predicted increase of 3.571, our main-bank-tied firm would have had a predicted 1984-87 fall of $(3.571-4.177=)-.606$. Hence the conclusion: main banks do not try to save the firms closest to them.

42 The mean increase in Main Bank Loan Share is 1.663 for 1981-84 and 1.495 for 1984-87. Neither is statistically significantly different from 0. 
Table 8: Determinants of Main Bank Share Increase:

\section{OLS Regression Results}

A. Prior to Distress:

\begin{tabular}{|c|c|c|c|c|c|c|c|c|}
\hline \multicolumn{9}{|c|}{ Dependent Variable: Main Bank Share Increase, 1981-1984 $(n=128)$} \\
\hline 81 MB Loan Share & -.080 & $(0.63)$ & -.072 & $(0.57)$ & -.067 & $(0.55)$ & -.051 & $(0.43)$ \\
\hline 81 MB Exper Dir (no.) & .718 & $(0.56)$ & & & & & & \\
\hline 81 MB Exper Dir (dum. & & & .271 & $(0.10)$ & & & & \\
\hline 81 Any Bk Exp Dir (no. & & & & & -.407 & $(0.87)$ & & \\
\hline 81 Any Bk Exp Dir (dur & & & & & & & -3.396 & (1) \\
\hline 81 Dominant $\mathrm{S} / \mathrm{h}$ & -2.973 & $(1.12)$ & -3.183 & $(1.20)$ & -3.484 & $(1.34)$ & -3.973 & (1.4 \\
\hline 81 Tot Bank Lns $\left(\times 10^{4}\right)$ & -.196 & $(2.02)$ & -.168 & $(1.91)$ & -.128 & $(1.62)$ & -.118 & $(1.61$ \\
\hline $\mathrm{R}^{2}$ & & .03 & & .03 & & .03 & & .04 \\
\hline
\end{tabular}

Dependent Variable: Main Bank Share Increase, 1978-1984 $(n=127)$

78 MB Loan Share $\quad-.268$ (2.75) $\quad-.229$ (2.42) $\quad \begin{array}{lllll}-.239 & \text { (2.58) } & -.230 \text { (2.50) }\end{array}$

78 MB Exper Dir (no.) 3.629 (1.40)

78 MB Exper Dir (dum.)

78 Any Bk Exp Dir (no.)

$-.284(0.09)$

78 Any Bk Exp Dir (dum.)

\begin{tabular}{|c|c|c|}
\hline & & $-.075(0.02)$ \\
\hline $3.956(1.65)$ & $-3.413(1.42)$ & $-3.909(1.51)$ \\
\hline$-.368(2.43)$ & $-.478(2.06)$ & $-.372(2.64)$ \\
\hline
\end{tabular}

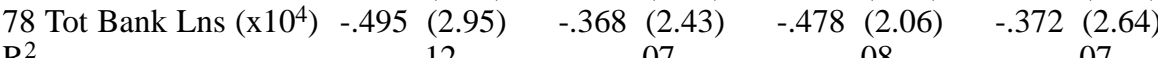

$\begin{array}{lllll}\mathrm{R}^{2} & .12 & .07 & .08 & .07\end{array}$

B. After distress:

Dependent Variable: Main Bank Share Increase, 1984-1987 $(n=119)$

84 MB Loan Share $\quad-.326(2.80) \quad-.320(2.72) \quad-.305$ (2.62) $\quad$-.307 (2.61)

84 MB Exper Dir (no.) 1.894 (1.85)

84 MB Exper Dir (dum.)

84 Any Bk Exp Dir (no.)

$3.236(1.55)$

84 Any Bk Exp Dir (dum.)

84 Dominant $\mathrm{S} / \mathrm{h} \quad-2.358(1.18) \quad-2.822(1.37) \quad-3.382(1.55) \quad-3.286(1.56)$

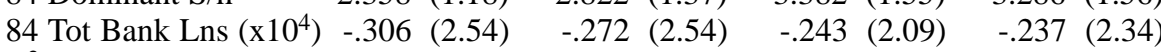

$\begin{array}{lllll}\mathrm{R}^{2} & .26 & .25 & .24 & .24\end{array}$

Dependent Variable: Main Bank Share Increase, $1984-1990(n=118)$

84 MB Loan Share $84 \quad-.702(4.08) \quad-.698$ (4.17) $\quad$-.672 (4.04) $\quad$-.676 (4.05)

84 MB Exper Dir (no.) 3.275 (1.97)

84 MB Exper Dir (dum.) 7.260 (1.97)

84 Any Bk Exp Dir (no.) 1.229 (1.15)

84 Any Bk Exp Dir (dum.) 4.424 (1.22)

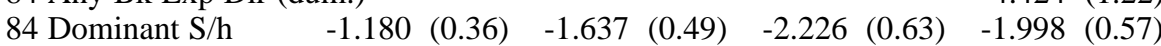

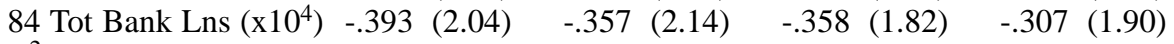

$\begin{array}{lllll}\mathrm{R}^{2} & .38 & .38 & .36 & .36\end{array}$

Sources: Toyo keizai tokei geppo, Apr. 1978; Shukan toyo keizai, Aug. 11, 1984; Kigyo keiretsu soran [Firm Keiretsu Overview] (Toyo keizai ed., as updated).

Notes: The data set is comprised of the 1984 firms, as explained in the text. In each case, we give the coefficients, followed by the absolute value of the t-statistics (calculated using OLS with robust standard errors) in parentheses. The regressions include a constant term, not reported here. 
d) Total bank loans. Faced with evidence that main banks do not increase their debt share at distressed firms, readers may suggest that main banks nonetheless help firms by inducing other banks to loan funds they otherwise would not lend. During their 1981-84 loss years, these troubled firms did increase their debt by 5\%. During the next three years (1984-87), they increased it by only $1 \%$, however, and during the height of the 1987-90 economic boom, they actually cut their debt (Table 6, Panel B).

TSE-listed firms as a whole increased their loans far more aggressively. During 1980-85, they increased the amounts they borrowed by $61 \%$ and, during 1986-90, by another $98 \%$. As noted earlier, the distressed firms were most commonly in the machinery, textiles, chemicals, steel, and trading industries. In these industries (textiles fall within light industry and steel within metals), the TSE firms raised their bank loans by the following fractions: ${ }^{43}$

1980-85:

\begin{tabular}{ccccc} 
Machinery & Light Ind. & Chemicals & Metals & Trading \\
\hline $22 \%$ & $101 \%$ & $23 \%$ & $101 \%$ & $142 \%$ \\
$84 \%$ & $72 \%$ & $25 \%$ & $142 \%$ & $335 \%$
\end{tabular}

Now consider Table 9, where we regress the increase in total loans (in percent) before and after the 1984 distress on the same independent variables. The only significant result concerns the number of directors with banking experience: the greater the number of such directors before the onset of distress, the lower the growth in a firm's total loans during the ensuing years (Panel A). The point relevant here, however, is simpler: the results show no evidence that strong main bank ties (whether by the main bank's share of the firm's loans or by its personnel on the firm's board) increase a firm's ability to borrow either before or after the onset of distress.

Summary measures confirm the absence of any mechanism by which main bank affiliation raises total loans. Of the 131 firms in our 1984 database with below-median Main Bank Loan Share in 1981, the amount of outstanding loans fell during 1981-84 at 13; of the firms with above-median Main Bank Loan Share, outstanding loans fell at 23. Of the firms with a below-median number of Main Bank Experience Directors in 1981, the amount of outstanding loans fell during 1981-84 at 18; of those with above-median Main Bank Experience Directors, outstanding loans similarly fell at 18.

43 Based on the database constructed for Miwa \& Ramseyer, Relationship Banking, supra note 2. 
Table 9: Determinants of Total Loan Increase: OLS Regression Results

A. Prior to Distress:

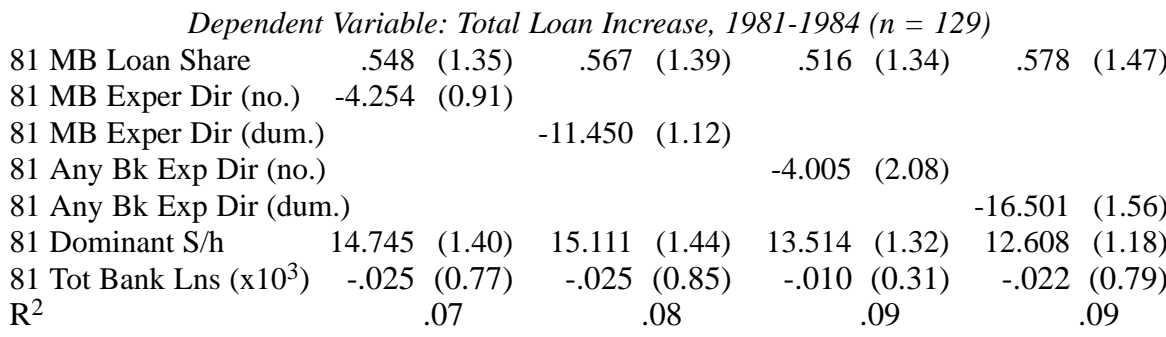

Dependent Variable: Total Loan Increase, 1978-1984 $(n=128)$

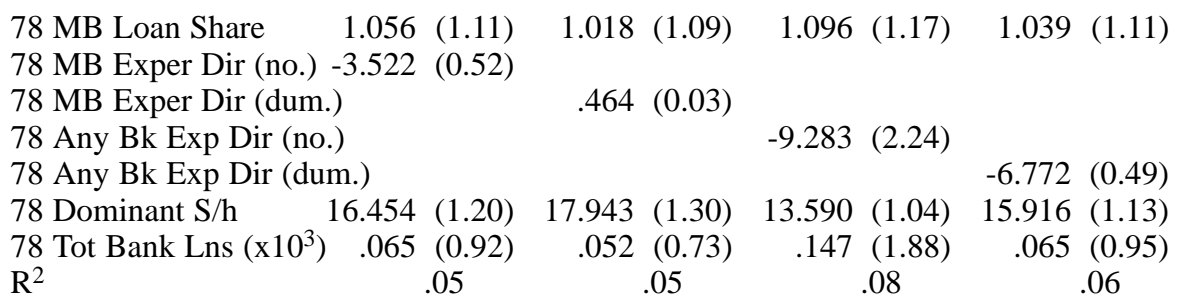

B. After Distress:

Dependent Variable: Total Loan Increase, 1984-1987 $(n=120)$

\begin{tabular}{|c|c|c|c|c|c|c|c|}
\hline hare & .734 & & .79 & $(0.8$ & $.742(0.83)$ & .780 & $(0.8$ \\
\hline MB Exper Dir (no.) & -.906 & $(0.13)$ & & & & & \\
\hline 4 MB Exper Dir (dum. & & & -14.612 & $(0.84)$ & & & \\
\hline 4 Any Bk Exp Dir (no. & & & & & $-2.427(0.61)$ & & \\
\hline 4 Any Bk Exp Dir (du & im.) & & & & & -18.303 & $(0.87)$ \\
\hline ominar & 34.795 & $(1.32)$ & 32.101 & $(1.26)$ & $33.390(1.27)$ & 30.275 & \\
\hline 84 Tot Bank Lns $\left(\times 10^{3}\right)$ & .082 & $(0.82)$ & .099 & $(1.03)$ & $.099(1.00)$ & .093 & $(1.07)$ \\
\hline & & .03 & & .03 & .03 & & .03 \\
\hline Dependent I & Varial & $\rho \cdot T_{0}$ & Ionn & creas & 8918 & 119) & \\
\hline MB Loan Share & 7.402 & $(0.95)$ & 7.658 & & $6.965(0.94)$ & 7.385 & $(0.97)$ \\
\hline MB Exper Dir (no.)- & -56.786 & $(1.15)$ & & & & & \\
\hline $4 \mathrm{M}$ & & & -192.754 & $(1.35)$ & & & \\
\hline $4 \mathrm{Ar}$ & & & & & $-33.083(1.29)$ & & \\
\hline 4 Any Bk & Іm.) & & & & & -216.075 & \\
\hline $\mathrm{S} / \mathrm{h} \quad 2$ & 248.885 & & 241.822 & & 257.933 (1. & 224.075 & \\
\hline 4 Tot Bank Lns $\left(x 10^{3}\right)$ & .539 & $(0.86)$ & .569 & $(0.93)$ & $.576(0.94)$ & .546 & $(0.93$ \\
\hline & & .06 & & 07 & .06 & & \\
\hline
\end{tabular}

Sources: Toyo keizai tokei geppo, Apr. 1978; Shukan toyo keizai, Aug. 11, 1984; Kigyo keiretsu soran [Firm Keiretsu Overview] (Toyo keizai ed., as updated).

Notes: The data set is comprised of the 1984 firms, as explained in the text. In each case, we give the coefficients, followed by the absolute value of the t-statistics (calculated using OLS with robust standard errors) in parentheses. The regressions include a constant term, not reported here. 
e) Main bank switch rates. If main banks offered implicit insurance against distress, then those firms closest to insolvency should maintain the most stable main bank relationships. Healthy thirty-five-year-olds do, after all, sometimes switch their life insurance policies. Terminally-ill eighty-yearolds do not. By hypothesis, the distressed firm has paid the bank its implicit insurance premia for years. At the very time at which it might collect on that policy, it will not cancel the policy and search for another carrier.

If distressed firms do switch main banks, they do so either because the main bank already reneged on its implicit insurance coverage or because it never offered it in the first place. And if main banks regularly renege, of course, no rational firm will pay the premia, while if firms do not pay the premia, no rational bank will offer the insurance. If distressed firms regularly switch main banks, firms and banks must not be contracting for insurance.

Firms do indeed switch. If anything (the difference is modest), distressed firms switch more readily than healthier firms. Of the firms in the 1978 database, $77(24.1 \%)$ had switched their main bank during the preceding three years. Among the 87 insolvent firms in the group, 32 (36.8\%) had switched. Among TSE firms as a whole, $29.2 \%$ changed their main bank affiliation during 1980-85; 20.8\% changed during 1986-90. Among the firms in the bottom profitability decile, $29.8 \%$ changed their main bank during the first half of the decade; $26.3 \%$ changed during the second.

f) Dominant shareholders. According to the corporate governance literature, the presence of a dominant shareholder will mitigate the conflict of interest between managers and shareholders. To be sure, a dominant shareholder may aggravate the conflict among the shareholders or between shareholders and creditors. Yet he should generally reduce the conflict between shareholders and managers and, in so doing, should raise firm performance.

So theory suggests. Yet our troubled firms include disproportionately many with a dominant shareholder. Among TSE Section 1 firms as a whole, $20.3 \%$ had a dominant (25\% or more) shareholder in 1980 and $20.4 \%$ in 1985 . Among our troubled 1978 firms, 39.0\% had a dominant shareholder (1977 data), while among our troubled 1984 firms 38.9\% did (1984 data). Among the 87 insolvent firms in our 1978 database, 43 had a dominant shareholder, of which only 26 survived to 1990 . At least in this sample, dominant shareholders seem unable to raise firm performance. Yet according to main bank theorists, what dominant shareholders cannot do banks routinely perform.

Return to Tables 8 and 9, where we ask whether dominant shareholders facilitated loans. Our account of the travails of Sasebo Heavy Industries suggests that dominant shareholders might do so by guaranteeing the troubled 
firm's loans. If they do, however, the results do not appear in Tables 8 and 9. The coefficients on Dominant Shareholder are uniformly insignificant.

Simple summary statistics illustrate how dominant shareholders seem not necessarily to increase the ability of firms to raise funds. Of the 51 firms in our 1984 database with a dominant shareholder in 1981, 15 firms $(29.4 \%)$ cut the amount they borrowed over 1981-84; of the 83 firms without a dominant shareholder, the amount of total loans fell at 21 firms (25.3\%).

\section{The Logic OF BANK Rescues}

Bankers do not spend their careers running industrial firms. They run banks. Through their work, they do not learn to build cars or sell detergents. They learn how to operate a heavily-regulated financial intermediary. They may, indeed, have been among the best students in their college class. But they need more than IQ to run a firm. Just as bureaucrats could not successfully run the Eastern European economy, bankers cannot run Japanese firms.

Talent is not expertise. "The biggest problem with having a bank control management," complained one businessman, "is that bankers can't stop thinking like bankers. Sure, they can cut personnel and inventory. But they don't seem to realize that even in the middle of all the cut-backs, you've got to plan for the future and invest in the right facilities." ${ }^{44}$ As Mansaku Takeda, senior consultant to the Daiichi Kangyo Bank, put it, "banks are places to oversee loans. There's no reason to think a banker has any talent for running a firm, and there're precious few examples of firms that did better because a banker came to run them. ... Sure, bankers may be smart. But whether they have any managerial talent is another issue." ${ }^{45}$

Despite the broad claims about bank monitoring and intervention in Japan, bankers accomplished much less. As one late-1970s account put it, bankers primarily intervened in firms with excessive investments. ${ }^{46}$ There, they did not need to run the firm. Instead, they needed only to arrive, to sell, and to leave.

Consistent with their slasher role, according to the same 1970s account, bankers primarily intervened either where the industry had long-term excess capacity or where a strong company CEO had ruled autocratically.

44 Ginko kanri [Bank Management], Shukan toyo keizai, Mar. 18, 1978, at 80, 87.

45 Mansaku Takeda, Ginko keiei no "genten" in kaeru toki [Returning to the Fundamentals of Bank Management], Shukan toyo keizai, Mar. 11, 1978, at 40, 41. 46 Ginko kanri, supra note 44, at 83. 
Newspapers called the late 1970s recession a "structural depression," and the structural changes fundamentally shifted Japanese comparative advantage. In many industries, firms were unlikely ever to recover to their earlier levels: sugar, some steel sectors, aluminum, shipbuilding, textiles, chemicals, paper, for example. Where the CEO had ruled autocratically, the firms had often gambled heavily in markets like real estate or built unnecessary plant capacity. Whether the firm was caught in a structural transformation or had gambled and lost, it needed someone with a talent for numbers to come, sell unneeded assets, and leave. That, bankers could do.

Given their limited ability, Japanese bankers avoid operating troubled debtors if possible. Like bankers elsewhere, they instead pull their loans when they can. So SHI and Hanasaki found, of course. When they needed extra money, the banks did not offer loans and volunteer to run the firm. Rather, they refused the money and pushed the firms toward bankruptcy. Whatever the pretext, explained one 1970s bank officer, "if a firm is in such bad shape that a bank will have to run it, banks will want to pull their loans if they can."47

By simple logic, if any entity were to "rescue" a firm, it would not be a bank. Instead, it would be an industrial firm and probably a business partner. First, such a firm would be more likely to have the expertise to overhaul the troubled firm. Because such a firm's executives ran an industrial operation themselves, they would know better than bankers how to revamp the firm. If from a business partner, they would even know the industry.

Second, an industrial firm would also have a stronger incentive to intervene than a bank. If firm $A$ "rescues" firm $B$, necessarily $A$ will increase $B$ 's stock price. An industrial firm can internalize that increase by buying $B$ stock and holding it as a subsidiary or internal division. A bank cannot. By law, a Japanese bank can hold only $5 \%$ of a firm.

When a rescue does occur in Japan (and tens of thousands of firms simply fail every year), the typical chronology begins with a non-financial firm that knows the distressed firm's business. Mazda, for example, could make good cars but needed to focus on marketing. The trading firms that handled its account stood to lose business if it folded and, for that reason, helped shift its managerial focus. To finance the transition, a troubled firm will often need funds and, for that purpose, may ask its banks for a loan. Mazda needed money and obtained it from its banks.

At root, the notion that Japanese bankers rescue firms parallels the notion that Japanese bureaucrats guide the economy. Traditionally, both banks and

$47 \quad I d$. at 84 . 
the government recruited smart college graduates, but IQ alone will not let a graduate build a car. Had bankers from the Sumitomo Bank really known enough to turn around Mazda, they would have done better to build the cars themselves. They did not build their own cars, of course, for the same reason neither they nor government bureaucrats engineered Mazda's transformation: they did not know how.

\section{Conclusions}

Despite the elaborate theory on point, our data on troubled firms from both the 1970s and the 1980s provide no support for claims that Japanese main banks rescue troubled firms - and if they do not rescue ex post, they do not implicitly agree to rescue ex ante. That should not surprise - for at the point of insolvency, banks and firms have fundamentally conflicting interests. The firm's employees and shareholders will welcome additional funds. The bank will not. It will not want to chase bad money with good, and even less will it want to chase the bad money only with its own good money, while the firm's shareholders and other lenders enjoy its obvious charity.

The stories about the "main bank system" are good stories — but at root they are only stories, and too good to be true at that. The elaborate Japan-specific theoretical permutations they foster may be attractive in the abstract, but bear no relation to bank-firm relations in fact. As in other countries, conflicts of interest matter in Japan. They matter now, and they mattered twenty and thirty years ago. They affect the structures firms adopt, the management strategies they pursue, and the deals they negotiate. A bit less modern theory and a bit more attention to basic conflicts of interest and we would understand a good bit more about Japanese business. 
